\title{
A revision of the genus Actephila (Phyllanthaceae) in the Malesian region
}

\author{
M. Heijkoop ${ }^{1}$, P.C. van Welzen ${ }^{1,2}$
}

Key words

Actephila

Asia

Malesia

Phyllanthaceae

revision

taxonomy

\begin{abstract}
The genus Actephila (Phyllanthaceae) is distributed from India in the north-west to Thailand and via Malesia to the Melanesian Islands and Australia in the south-east. Eleven species are recognized of which three are newly described, $A$. discoidea with long leaf apices and a fleshy nectar discs, $A$. emarginata with an emarginate leaf base, and $A$. stipularis with large stipules. Further, $A$. javanica is synonymized with $A$. excelsa; and a former synonym or separate variety, $A$. excelsa var. acuminata, is recognized as distinct species, but had to be synonymized under A. subsessilis. Actephila puberula, not present in Malesia, but often synonymized with $A$. excelsa, is kept separate because of the hairy ovary and different base of the leaf blades.
\end{abstract}

Published on 31 January 2017

\section{INTRODUCTION}

Actephila Blume consists of (sub)shrubs to small trees. Its distribution ranges from India in the north-west to Thailand and via Malesia to the Melanesian Islands and Australia in the southeast. Actephila is classified in family Phyllanthaceae (formerly part of Euphorbiaceae s.I.), tribe Poranthereae (Forster 2005, Hoffmann et al. 2006, Vorontsova \& Hoffmann 2008).

The genus was first described by Blume in 1826, but he did not mention any species; he only referred to a collecting locality in Java and additional collection data. Later Hasskarl (1844) included the genus in Savia Willd. and described Savia actephila Hassk. Actephila was reinstated by Miquel (1859) and he renamed S. actephila to Actephila javanica Miq. This is the only species from the same location (Nusa Kambangan Island) that was mentioned by Blume in his genus description. Miquel (1859) also described A. bantamensis Miq. from W Java, here considered to be a synonym of $A$. javanica.

The species are common in the rain forest understorey with mostly small trees (up to $5 \mathrm{~m}$ ) and a few species as higher trees (up to $15 \mathrm{~m}$ ). The genus is characterized by the presence of stiff, caducous, somewhat deltoid or triangular stipules at the base of the petioles; very small, straight, simple, caducous hairs on all parts; penninerved leaves; axillary, usually single, small unisexual flowers with $0-6$ petals much smaller than the 5 or 6 sepals; a circular disc surrounding the stamens or ovary, and the woody fruits, with often a knobbly surface, which are septicidally or loculicidally dehiscent and supported by a persistent and sometimes enlarging calyx. Typical for Phyllanthaceae is the presence of two ovules per locule and solitary or fasciculate axillary flowers (partly after Radcliffe-Smith 2001, Vorontsova \& Hoffmann 2008).

The taxonomic placement of the genus Actephila has changed several times. An initial classification of Euphorbiaceae s.l. by Müller (1866) placed the genus Actephila in the tribe Phyllantheae subtribe Savieae (Forster 2005). During the 20th

\footnotetext{
1 Naturalis Biodiversity Center, Botany, P.O. Box 9517, 2300 RA Leiden, The Netherlands; corresponding author e-mail: peter.vanwelzen@naturalis.nl.

2 Institute of Biology Leiden, Leiden University, P.O. Box 9505, 2300 RA Leiden, The Netherlands.
}

century Pax \& Hoffmann $(1922,1931)$ included Actephila in the subfamily Pyllanthoideae subtribe Amanoinae. The placement changed again when Webster $(1994,2014)$ included the genus in subfamily Phyllanthoideae tribe Wielandieae, a classification followed by Radcliffe-Smith (2001). More recently, it has been proposed to recognize the subfamily Phyllanthoideae again at the family level as the Phyllanthaceae (Chase et al. 2002, APG 2003). Molecular analysis of genera placed in Phyllanthaceae revealed that Actephila is closely related with the genera Andrachne L. and Leptopus Decne., and less so to Meineckia Baill., Poranthera Rudge, and Zimmermannia Pax (Wurdack et al. 2004, Samuel et al. 2005). In the most recent classification by Vorontsova \& Hoffmann (2008) Actephila was placed in the tribe Poranthereae.

Unfortunately most revisions are outdated. The last complete revision of Actephila was by Pax \& Hoffmann (1922). The only recent revisions of the genus were for Thailand (Chayamarit 2005) and the Australian region, where the number of species increased from five to 14 (Forster 2005). We had similar results with the revision of the Malesian species, new species are described and several names are synonymized.

The present revision of the Malesian species of Actephila shows that the variation within certain species is very high, especially in $A$. excelsa (including $A$. javanica var. javanica) and $A$. lindleyi (Steud.) Airy Shaw. Because of the high variability and small differences between species, species delimitation is difficult, which explains why in the past many specimens were incorrectly identified or new species were not recognized. For example, Actephila excelsa (Dalzell) Müll.Arg. and $A$. javanica represent a complex species within Malesia. They are variously treated as separate species (e.g., Chayamarit 2005), as synonyms (this treatment) or as separate varieties of a single species (e.g., Airy Shaw 1972).

In this revision eleven species are recognized, of which six were already known as species and one as a variety. Actephila collinsae Hunter is excluded as it only occurs in Thailand, outside the Malesian region. Actephila mooreana Baill. ('mooriana') was formerly synonymized with $A$. lindleyi, but is distinct. It occurs exclusively in Australia, where A. lindleyi is in fact absent (a description of $A$. mooreana can be found under $A$. lindleyi in 
the revision by Forster 2005). Actephila puberula Kurz, usually considered as a synonym or variety of $A$. excelsa, is regarded as a distinct species of the Andaman islands as the leaf blade base is rounder to even slightly emarginate and the ovary is densely hairy instead of glabrous. Actephila excelsa var. acuminata Airy Shaw appeared to be distinct from the rest of $A$. excelsa, but conspecific with the Vietnamese $A$. subsessilis Gagnep., the older and thus accepted name. Recently, $A$. alanbakeri Welzen \& Ent (Van der Ent et al. 2016) was described and here three species are newly recognized: $A$. discoidea Heijkoop \& Welzen, A. emarginata Heijkoop \& Welzen, and $A$. stipularis Heijkoop $\&$ Welzen. This revision was solely based on morphological features.

The aim of this study is to revise the Malesian species in the genus Actephila, which will be part of the ongoing revision of the Euphorbiaceae for the international Flora Malesiana Project (published work already visible via www.nationaalherbarium. $\mathrm{nl} /$ euphorbs).

\section{MORPHOLOGICALLY IMPORTANT CHARACTERS}

Characters used for species recognition are indumentum, stipule shape and size, petiole length, size of the leaf blade, shape of the leaf blade base and apex, pedicel length and shape, flower structures, thickness of the nectar disc, structure of the fruit wall surface, size and shape of the columella, and size of the calyx.

\section{Indumentum}

All species are subglabrous and possess small, sericeous or puberulous simple hairs only, which can be seen with high magnification only. These hairs occur on all young plant parts and are often early caducuous, which makes the plants seemingly glabrous with the exception of $A$. ovalis (Ridl.) Gage, $A$. subsessilis and $A$. trichogyna Airy Shaw, which often have a more dense covering. Places where hairs are more persistent are the branch tips, sepals, sometimes on or near brachyblasts or in the axils of leaves. In most species indumentum is occasionally found on the abaxial leaf blade with more hairs towards the blade base. If present, hairs on the main veins are mostly persistent.

\section{Leaf morphology}

Stipules are deltoid to triangular in shape, stiff, usually glabrous and caducous. Some species have hairy stipules towards the branch ends (e.g., A. ovalis).

The petioles are either completely pulvinate when short or pulvinate at base and apex when longer.

The phyllotaxy is alternate, but as internodes become very short towards the end of the branches, the terminal leaves appear to be (sub)opposite. Moreover, most species have a somewhat intermittent growth (often named Terminalia branching), whereby a longer internode alternates with several short ones that bear leaves, thus leaving the impression that leaves are in whorls or opposite. The leaf blades are generally elliptic to somewhat ovate or obovate, though those of $A$. alanbakeri are much more narrow.

The venation is pinnate, with the secondary veins looped and joined near the margin. The tertiary and higher order veins are reticulate. The venation is somewhat elevated on both surfaces, but most distinct on the abaxial surface.

The blade thickness varies from pergamentaceous (e.g., A. latifolia Benth.) to papyraceous (e.g., A. ovalis). It sometimes varies within a species (e.g., A. excelsa), which is probably due to environmental conditions.
The base of the leaf blade varies from attenuate (e.g., A. lindleyi) to acute or somewhat obtuse (e.g., A. excelsa); $A$. emarginata is unique with an emarginate leaf base (Fig. 4). The apex varies from obtuse to acute (e.g., A. trichogyna), to acuminate to cuspidate (e.g., A. excelsa).

\section{Inflorescences and flowers}

Inflorescences are usually absent and the flowers generally grow solitary or paired in leaf axils, sometimes in larger fascicles. Repeated flowering from the same axils (leafless after the first season) results in thickened brachyblasts on the stem or thick branches from which short racemes grow with new generations of flowers (e.g., A. lindleyi; Fig. 5).

All species appear to be dioecious, because only either staminate or pistillate specimens were found on the same specimen. All flowers are 5-merous with five sepals, petals and stamens when staminate. The sepals are often somewhat ovate to more elliptic or obovate. Petals are very small, much smaller than the sepals; they are obovate and distinctly narrowed towards the base.

The stamens are either free (e.g., A. excelsa) or connate at base (e.g., A. lindleyi). Stamens are 2-thecate with the thecae dorsally connected to the connective. The staminate flowers have a circular, somewhat lobed disc surrounding the stamens, which is either thin (e.g., A. excelsa) or fleshy (e.g., A. trichogyna). In between the stamens a 3-branched pistillode is present except in A. trichogyna, which shows a bundle of hairs instead.

The pistillate flowers usually have longer pedicels than the staminate flowers. A 3-locular ovary is present, with two ovules per locule. Three sessile stigmas are found directly on top of the ovary, each is apically bifid. The circular disc resembles that of the staminate flowers in shape.

\section{Fruits and seeds}

Pedicels range from short and sturdy (e.g., A. lindleyi) to somewhat longer and often curved and thickening towards the apex (e.g., A. excelsa) to long and delicate (e.g., A. ovalis).

The fruits are subglobular as they are somewhat flattened and 3-lobed. They open septicidally and loculicidally along 6 lines of dehiscence. These lines are usually fine but distinct and not elevated (e.g., A. lindleyi); however, in A. excelsa they are sometimes slightly elevated, and in $A$. alanbakeri the lines of dehiscence consist of six wide sutures (Fig. 1). In contrast, $A$. stipularis possesses very fine, indistinct lines of dehiscence.

The somewhat woody wall consists of two distinct layers, with the outer layer (exocarp) detaching from the inner layer (woody meso- and endocarp) after dehiscence. Usually the fruits have a knobbly surface (e.g., $A$. excelsa), though some species have a more corkey $(A$. alanbakeri; Fig. 1$)$, smooth $(A$. stipularis; Fig. 7 ) or slightly reticulate surface $(A$. subsessilis). Fruits are almost always glabrous, though sometimes microscopic hairs are present (e.g., sometimes in A. excelsa) or with larger hairs, visible with the naked eye, in $A$. ovalis and $A$. trichogyna. Sepals of the pistillate flower are persistent in fruit, these are usually not elongating, except in A. ovalis (Fig. 6; and several other species in Thailand and Indochina).

All species have fruits which (can) contain up to six seeds, two seeds per locule. The seeds are abaxially round with straight side walls, and are sharply triangular in cross-section adaxially (Fig. 2d right). When only a single ovule in the locule develops, a single larger seed is found (Fig. $2 \mathrm{~d}$ left, often shaped like two seeds fused together. 


\section{TAXONOMY}

\section{Actephila}

Actephila Blume (1826) 581; Endl. (1840) 1123; Miq. (1859) 356; Müll.Arg (1863) 77; (1866) 221; Benth. (1873) 88; Kurz (1877) 340; Benth. (1880) 269; Hook.f. (1887) 282; F.M.Bailey (1902) 1413; J.J.Sm. (1910) 45; Pax \& K.Hoffm. (1922) 191; Ridl. (1924) 196; Gagnep. (1927) 530; Backer \& Bakh.f. (1963) 470; Airy Shaw (1971) 496; (1972) 208; Whitmore (1973) 51; Airy Shaw (1975) 25; (1980a) 21; (1980b) 217; (1980c) 586; (1981) 248; (1982) 4; (1983) 3; G.L.Webster (1994) 37; Govaerts, Frodin \& Radcl.-Sm. (2000) 112; Radcl.-Sm. (2001) 10; Chayam. (2005) 34; P.I.Forst. (2005) 63; Voronts. \& Petra Hoffm. (2008) 46; G.L.Webster (2014) 66. — Savia Willd. sect. Actephila (Blume) Baill. (1858) 571, t. 26, f. 24. - Type (see note 1): Actephila javanica Miq. [= Actephila excelsa (Dalzell) Müll.Arg.]. Lithoxylon Endl. (1840) 1122; Baill. (1858) 590; Müll.Arg. (1866) 232. — Type: Lithoxylon lindleyi Steud. [= Actephila lindleyi (Steud.) Airy Shaw].

Anomospermum Dalzell (Aug. 1851) 228, nom. illeg. (non Miers, Jan. 1851, Menispermaceae). - Type: Anomospermum excelsum Dalzell [= Actephila excelsa (Dalzell) Müll.Arg.].

(Sub)shrubs to trees, monoecious; long internodes often alternating with several short ones, flowering branches round in section, with scars of fallen leaves, often flattened apically, striate when dry. Indumentum of short, simple, straight hairs, generally most parts subglabrous or glabrescent. Stipules stiff, apex acute, early caducous. Leaves alternate to often subopposite near branch ends, simple; petiole round but flat or channelled above, completely pulvinate or basally and apically pulvinate; blade elliptic, symmetric, papyraceous to pergamentaceous, margin entire, recurved, adaxially glabrous; venation raised on both sides when dry, pinnate, secondary nerves looped and joined near the margin, tertiary veins and veinlets distinct, reticulate. Flowers solitary, paired or fascicled, generally axillary, when cauli- or ramiflorous then often in short racemes on thickened brachyblasts, 5-merous; sepals 5, imbricate, basally united, margin entire, outside somewhat sericeous, inside generally glabrous; petals 5 (Malesia), much smaller than sepals, obovate or obtriangular, base narrow, glabrous on both sides; disc a thin or fleshy ring around stamens or ovary, somewhat lobed. Staminate flowers: pedicel short; stamens 5, free or connate at base, anthers dorsibasifixed, 2-thecate, thecae parallel, opening latrorse via lengthwise slits; pistillode a dot of hairs or 3-branched and glabrous. Pistillate flowers: sepals persistent; petals semi-persistent; ovary 3-locular, ellipsoid, 2 ovules per locule, style absent, stigmas short, 3-branched, apically split, tips slightly thickened, bent horizontally, persistent. Fruits capsules, subglobose, generally apically flattened, 3-lobed, opening completely septicidally and loculicidally; pedicels round in cross-section; sepals in some species enlarging; petals often caducous; wall usually knobbly, with 6 generally distinct lines of dehiscence, outer layer detaching from inner layer, latter somewhat woody; columella T-shaped, basally thickened. Seeds abaxially round, side walls straight, trigonous, smooth, without aril or caruncle; sometimes with widened abnormally shaped seeds when 1 ovule develops per locule, adaxially round with a longitudinal rib dividing it in 2 equal parts, abaxially flat, widely V-shaped, somewhat diamond shaped in cross-section.

Distribution - An Asian to Australasian and West Pacific genus of c. 25 species. In Malesia eleven species occur.

Note - Blume (1826) only published the genus name, he never described a species. However, he noted that the specimen he described came from the island Nusa Kambangan near Java. The only species Miquel described from this island, with reference to Blume, is A. javanica (basionym Savia actephila) and accordingly, we selected a specimen of Blume from Nusa Kambangan as lectotype of Savia actephila and as type of the genus Actephila.

\section{KEY TO THE SPECIES}

1. Base of leaf blade generally emarginate with sometimes a few leaves with a more obtuse base. - New Guinea

4. A. emarginata

1. Base of leaf blade attenuate, obtuse or acute, never emarginate.................. 2

2. Calyx in fruit enlarged with sepals (10-)13-22 by $9-15$ $\mathrm{mm}$. Leaf blade margin wavy. Stipules outside strongly sericeous when young. ............ 8. A. ovalis

2. Calyx in fruit not to slightly enlarged with sepals $1.3-6$ by $1-4.5(-5) \mathrm{mm}$. Leaf blade margin flat. Stipules outside glabrous to only somewhat sericeous when young ... . 3

3. Stipules large, c. 8 by $3 \mathrm{~mm}$. - Sulawesi . 9. A. stipularis

3. Stipules small, $0.8-4$ by $0.5-2 \mathrm{~mm}$. - Outside Sulawesi 4

4. Plants from Thailand, Malay Peninsula, Sumatra, Java, Borneo, the Philippines, Sulawesi . . . . . . . . . . 5

4. Plants from New Guinea, Moluccas, Lesser Sunda Islands $\ldots \ldots \ldots \ldots \ldots \ldots \ldots \ldots \ldots \ldots \ldots \ldots \ldots \ldots \ldots \ldots \ldots \ldots$

5. Fruits with wrinkled corky surface, glabrous, with 6 deep, wide sutures. Leaf blades narrowly ovate to narrowly elliptic, $8-24.5$ by $1.6-4.9(-7.2) \mathrm{cm}, 3.3-5.9$ times as long as wide. - Ultramafic soils in the Philippines and Borneo 1. A. alanbakeri

5. Fruits with knobbly, glabrous to somewhat sericeous surface, with 6 fine lines of dehiscence, sometimes slightly elevated, usually not elevated. Leaf blades elliptic (to \pm obovate), $5.5-$ 35.5 by $(1.1-) 1.9-13.5(-15.9) \mathrm{cm}, 1.9-3.7(-8)$ times as long as wide. . . . . . . . . . . . 6

6. Petioles 5-95 mm long; leaf blades elliptic (to \pm obovate), $5.5-35.5$ by $(1.1-) 1.9-13.5(-15.9) \mathrm{cm}$. Pistillate flowers white to greenish. Fruit wall with knobbly surface, venation not raised; columella 5-8 mm long, basally somewhat thickened but not completely covering disc and base of sepals 5. A. excelsa

6. Petioles $1-6(-8) \mathrm{mm}$ long; leaf blades elliptic, $5.6-15$ by $2.1-5.2 \mathrm{~cm}$. Pistillate flowers yellow. Fruit wall with slightly knobbly surface and somewhat elevated venation pattern; columella 4-6 mm long, basally completely covering disc and base of sepals. - Thailand, Malay Peninsula . . . . .

10. A. subsessilis

7. Plants from Moluccas (Aru Islands) and Lesser Sunda Islands . . . . . . . . . . . . . . . . . . 8

7. Plants from New Guinea . . . . . . . . . . . . . . 9

8. Disc a thick, fleshy, wide ring, substantially covering sepal base in fruit. Stipules $0.8-1.3$ by $0.8-1.3 \mathrm{~mm}$, often somewhat folded horizontally. Pistillate pedicel $6-35 \mathrm{~mm}$ long. Fruiting pedicels $15-35$ by $0.7-0.8 \mathrm{~mm}$. Sepals in fruit elliptic to obovate, widest just above to in the middle, $4.5-5(-5.5)$ by $2.5-4.5(-5) \mathrm{mm}$. Stigmas $0.8-2 \mathrm{~mm}$ long. - Lesser Sunda- and Aru Islands ... 6. A. latifolia

8. Disc a thin, narrow, papery ring, slightly covering sepal base in fruit. Stipules generally $1.2-3$ by $1-2 \mathrm{~mm}$, straight in the middle. Pistillate pedicel c. $3 \mathrm{~mm}$ long. Fruiting pedicels $6-15(-40)$ by $(0.5-) 0.9-2(-2.5) \mathrm{mm}$. Sepals in fruit broadly ovate or deltoid to ovate to elliptic, widest at base to just in the middle, $1.3-2.5(-3)$ by $1.3-2(-2.5) \mathrm{mm}$. Stigmas $0.4-0.6 \mathrm{~mm}$ long. - Moluccas ... 7. A. lindleyi

9. Pistillate disc clearly visible . . . . . . . . . . 10

9. Pistillate disc unclear or flowers staminate or specimen sterile....................... 13

10. Pistillate disc narrow, thin and papery, slightly covering sepal base in fruit . . . . . . . . . . . . 7. A. lindleyi

10. Pistillate disc wide, thick and fleshy, substantially covering sepal base in fruit $\ldots \ldots \ldots \ldots \ldots \ldots \ldots \ldots$ 
11. Indumentum of very short papillae-like hairs on especially the younger branches, petioles, leaf blades. Fruiting pedicels $27-85 \mathrm{~mm}$ long. Stipules $0.8-1.6$ by $0.5-0.9 \mathrm{~mm}$. 3. A. dolichopoda

11. Indumentum on branches, petioles and leaf blades either absent, or simple short, somewhat sericeous or puberulous hairs, never papillae-like. Fruiting pedicels $7-20(-25) \mathrm{mm}$ long. Stipules $1.5-3$ by $0.8-2 \mathrm{~mm} \ldots \ldots \ldots \ldots 12$

12. Fruits glabrous. Petioles $5-38 \mathrm{~mm}$ long; blades $11-30.5$ by $2.6-9.3,2.6-4.3$ times as long as wide, apex gradually tapering into a widely caudate apex. Pistillode in staminate flower unknown (but plant itself is largely glabrous) . . . . ... . . . . . . . . . . . . . . . . 2. A. discoidea

12. Fruits hairy. Petioles $2-4 \mathrm{~mm}$ long; blades $5.4-9$ by $2.9-$ $4.1 \mathrm{~cm}, 1.9-2.2$ times as long as wide, apex obtuse to somewhat acuminate. Pistillode in staminate flower a bundle of hairs ............. A. trichogyna

13. Leaf blade base generally attenuate, sometimes with a few leaves with a more acute base ....... 7. A. lindleyi

13. Leaf blade base acute or obtuse, never attenuate . . 14
14. Fruits sericeous (when developing). Leaf blades 5.4-9 by $2.9-4.1 \mathrm{~cm}$, generally $1.9-2.2$ times as long as wide. Petioles 2-4 mm long . . . . . . . . 11. A. trichogyna

14. Fruits glabrous. Leaf blades $7-30.5$ by $2.6-9.3 \mathrm{~cm}$, generally $2.4-4.3(-5.1)$ times as long as wide. Petioles $5-38$

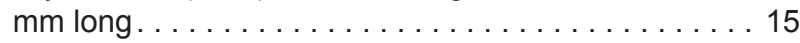

15. Most parts usually subglabrous, being somewhat sericeous or glabrous. Stipules $1.5-3$ by $1.2-2 \mathrm{~mm}$. Leaf blades ovate to elliptic, $11-30.5$ by $2.6-9.3 \mathrm{~cm}, 2.6-4.3(-5.1)$ times as long as wide. Fruiting pedicels $7-20(-25) \mathrm{mm}$ long . . . . . . . . . . . . . . . . 2. A. discoidea

15. Most parts like branches, petioles and leaf blades usually (sub)glabrous, but especially younger parts with papillaelike hairs, sepals outside somewhat sericeous. Stipules $0.8-1.6$ by $0.5-0.9 \mathrm{~mm}$. Leaf blades elliptic to somewhat obovate, $7-16.3$ by $2.7-6.8 \mathrm{~cm}, 2.4-2.9$ times as long as wide. Fruiting pedicels $27-85 \mathrm{~mm}$ long 3 . A. dolichopoda

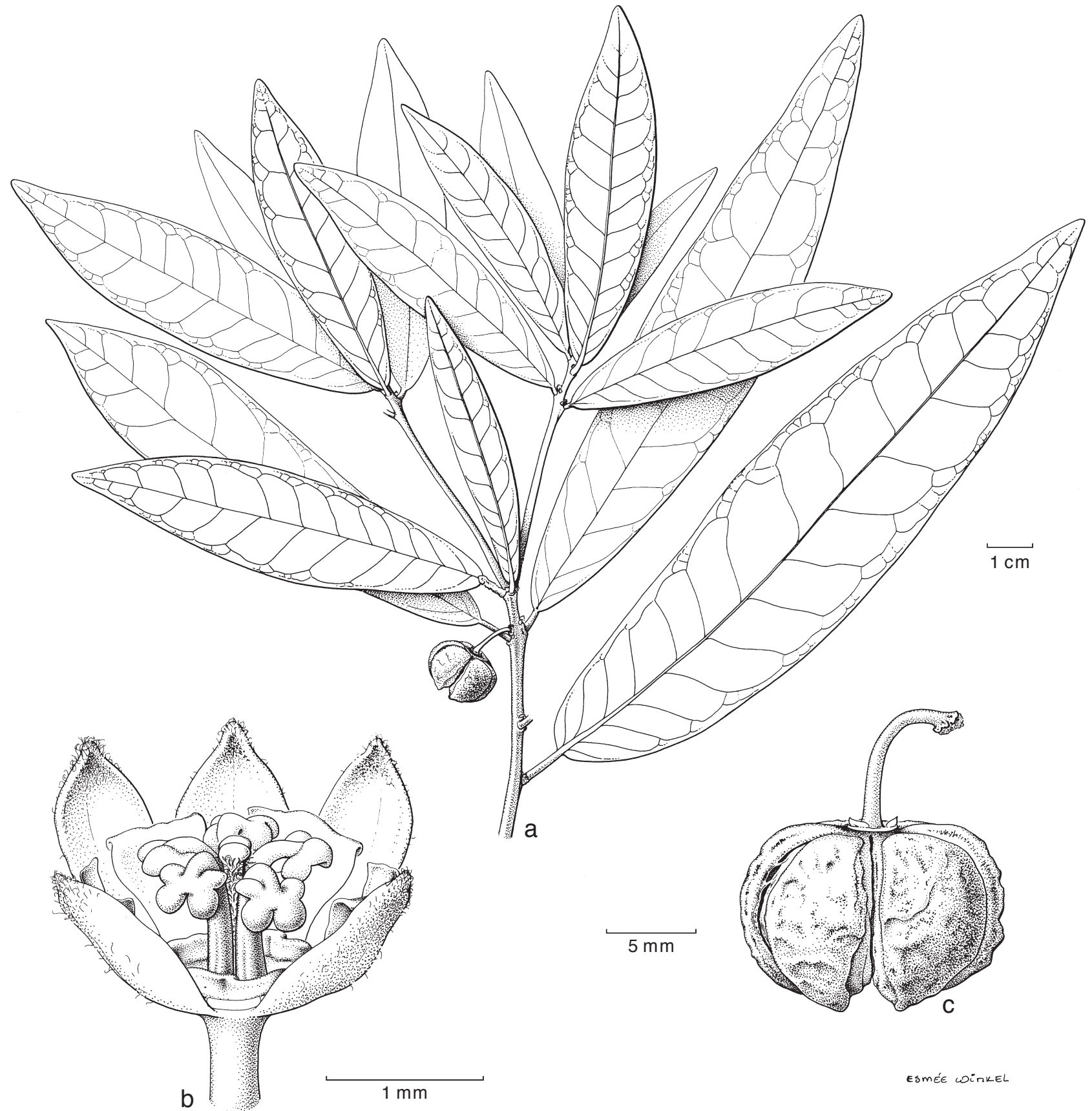

Fig. 1 Actephila alanbakeri Welzen \& Ent (Phyllanthaceae; formerly Euphorbiaceae). a. Habit; b. staminate flower, front petal removed; c. dehiscing fruit (a, c: SAN (John B.S. \& Dauni S.) 145750; b: SNP 38539). — Drawing by Esmée Winkel, 2015. 


\section{Actephila alanbakeri Welzen \& Ent - Fig. 1; Map 1}

Actephila alanbakeri Welzen \& Ent in Van der Ent et al. (2016) 2. - Type: SNP (Van der Ent et al.) 38539 (holo SNP; iso L), Malaysia, Sabah, Kinabalu Park, Nalumad. Paratype: SAN (Sugau \& Seligi) 145750 (L, SAN), Malaysia, Saba, Kudat Distr., Malawali Island.

Shrubs to trees, up to $3 \mathrm{~m}$ high, dbh up to $6 \mathrm{~cm}$; flowering branches angular when dry, glabrous, 2-8 $\mathrm{mm}$ diam. Indumentum on brachyblasts and sepals, otherwise glabrous. Stipules triangular to deltoid or broadly ovate, $1.1-1.6$ by (0.5-)0.8-1.3 mm. Leaves: petioles 4-30 mm long, green to maroon, heavily wrinkled when dry, pulvinate on both sides to completely pulvinate, pulvini becoming corky with age; blade narrowly ovate to narrowly elliptic, $8-24.5$ by $1.6-4.9(-7.2)$ $\mathrm{cm}, 3.3-5.9$ times as long as wide, papyraceous to pergamentaceous, base acute to obtuse, margin flat, apex acute or gradually tapering into a widely cuspidate apex, tip acute to obtuse, adaxially green, abaxially pale green, glabrous; nerves 15-20(-26) per side. Flowers solitary, on small brachyblasts with age; sepals apex acute to obtuse; disc a narrow thin ring. Staminate flowers c. $3 \mathrm{~mm}$ diam; pedicel short, not widening towards apex, glabrous; sepals ovate, widest just below the middle, reddish; petals apex truncate to somewhat wavy, glabrous, white to pinkish; stamens connate at base. Pistillate flowers (from photograph): sepals dark pink, ovate to broadly ovate, widest at base, c. 1 by $1.4 \mathrm{~mm}$ (as observed in fruit); petals white; disc yellow; ovary glabrous, stigmas yellow. Fruits green (immature) to brown (mature), $1.4-2 \mathrm{~cm}$ diam, pendent, glabrous; pedicels $7-33$ by $0.75-1.5 \mathrm{~mm}$, usually not widening towards apex; sepals not elongating; fruit wall with corky wrinkled surface, 3-lobed, lines of dehiscence consisting of 6 deep wide sutures, distinct, outer layer with strongly reticulate lines on the inside, somewhat elevated, somewhat woody, thick; columella c. $7 \mathrm{~mm}$ long, somewhat fibrous after dehiscence, basally completely covering disc and hanging over the base of sepals. Seeds c. $10 \mathrm{~mm}$ long, c. $8 \mathrm{~mm}$ wide, c. $7 \mathrm{~mm}$ high; widened seeds not seen.

Distribution - Borneo, the Philippines.

Habitat \& Ecology — Ultramafic forests, mangrove forests, along the beach, on gentle slopes. Soil: Ultramafics or limestone. Altitude: sea-level to $90 \mathrm{~m}$. Fruiting: June, August, October.

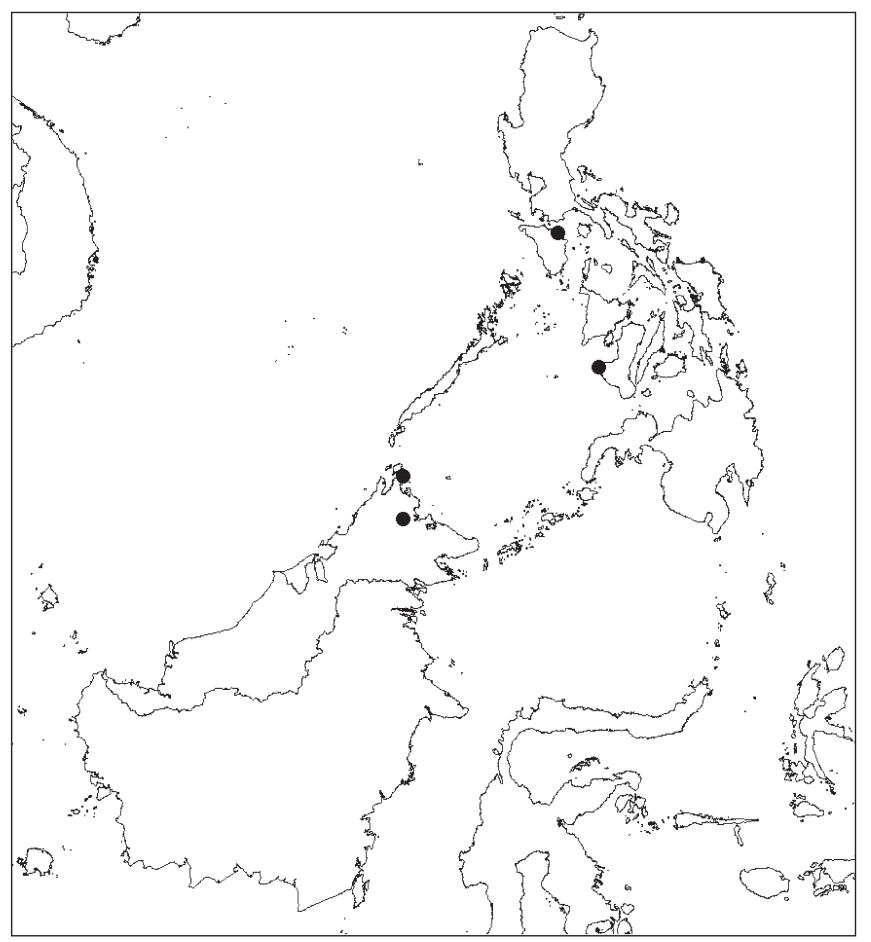

Map 1 Distribution of Actephila alanbakeri Welzen \& Ent
Notes - 1. Typical for this species are the fruits with a wrinkled, thick, somewhat corky fruit wall when dry, and 6 wide sutures when fresh. The base of the columella in adult fruits is relatively wide and completely covering the persistent disc, the calyx is persistent but indistinct with small sepals. Additionally these plants are able to survive on ultramafic soils.

2. This species is hard to distinguish from $A$. lindleyi vegetatively, however, the stipules are in general shorter and narrower, the leaf blades have an acute or obtuse base instead of an attenuate base, and the species has in general 15-20 nerves per side of the midrib, while $A$. lindleyi only has in general 7-14 nerves per side of the midrib. Actephila alanbakeri is found in Borneo and in the Philippines, while A. lindleyi is known from New Guinea and the Moluccas.

3. The species was only known from ultrabasic soil in Sabah. Recently, two specimens from the Philippines ( $P N H$ (Celestino \& Castro) 1932 from Mindoro, and PPI (Madulid \& Majaducon) 36047 from Danjugan Island) could be added. However, it is unclear if these specimens were also growing on ultrabasic soil. Mindoro has ultrabasic soil, but for Danjugan information is lacking. The PNH specimen has no ecological information, and the PPI label is confusing, it indicates that the specimen was collected in beech and mangrove forest, but at an altitude of $50 \mathrm{~m}$.

2. Actephila discoidea Heijkoop \& Welzen, sp. nov. - Fig. 2; Map 2

Resembling $A$. lindleyi by the short, straight fruiting pedicels and relatively short, often completely glabrous petioles. Differing from $A$. lindleyi in leaf shape being often ovate, with the base often acute and the apex usually longer, and the presence of a thick, fleshy nectar disc (vs leaf blade elliptic (to obovate), base usually attenuate, apex usually acute, disc thin in $A$. lindleyi). - Type: Takeuchi \& Towati 14639 (holo L; iso probably in A, LAE), Papua New Guinea, Morobe Province, Kamiali Wildlife Management Area, ridge inland of Cape Roon, slopes above side baret of the Ariwiri River, near S0 $7^{\circ} 19.6^{\prime} \mathrm{E} 147^{\circ} 07.5^{\prime}$

Shrubs to tree(let)s, 1-5 m high, monocaulous to sparsely branched; flowering branches 2-4 mm diam, with brown lenticels, sometimes somewhat puberulous at branch tips. Indumentum: most parts subglabrous. Stipules deltoid to broadly ovate, $1.5-3$ by $1.2-2 \mathrm{~mm}$, glabrous. Leaves: petioles $0.5-3.8 \mathrm{~cm}$ long, pulvinate at both ends, often glabrous, sometimes slightly sericeous, striate when dry, sometimes with transverse grooves, somewhat corky when older; blade ovate to elliptic, $11-30.5$ by $2.6-9.3 \mathrm{~cm}, 2.6-4.3(-5.1)$ times as long as wide, fleshy when fresh, papyraceous when dry, base obtuse to acute, margin flat, apex gradually tapering, widely caudate to cuspidate, tip acute, adaxially dull to glossy, light to dark green, abaxially paler green than adaxially to yellow-green or slightly glaucous, glabrous; nerves 9-14 per side. Flowers solitary, on brachyblasts when older. Staminate flowers not seen. Pistillate flowers not seen, observations from fruit: sepals broadly ovate, widest at base, c. 3 by $2-2.5 \mathrm{~mm}$, apex acute to obtuse, often glabrous on both sides; disc a thick fleshy, wide ring, substantially covering the base of sepals in fruit. Fruits dull, immature glaucous green to green, $1.5-1.7 \mathrm{~cm}$ diam, erect, glabrous; pedicels 7-20(-25) by $1-2 \mathrm{~mm}$, usually not thickening towards apex, straight, edges smooth, glabrous (to slightly sericeous); sepals not elongating, reflexed; wall with knobbly surface, thin, lines of dehiscence not elevated; columella 6-11 mm long, fibrous after dehiscence. Seeds 8-12 mm long, 5-9 $\mathrm{mm}$ wide, 5-7 $\mathrm{mm}$ high; widened seeds not seen.

Distribution - New Guinea.

Habitat \& Ecology - Primary lowland (dipterocarp) rain forests. Soil: clay, rocks, ultrabasic soil. Altitude: sea-level to 430 m. Fruiting: March, April, July, August, November. 


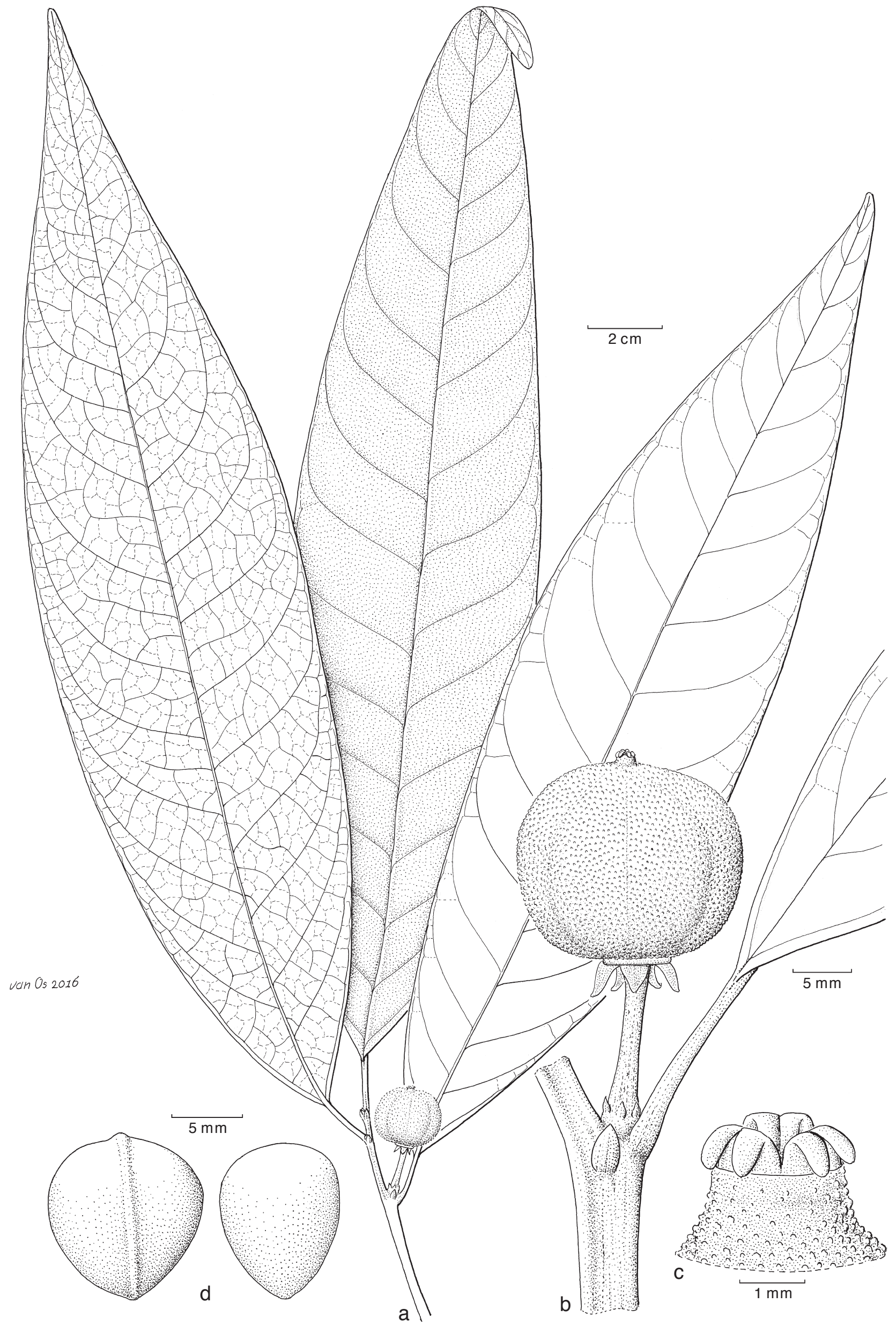

Fig. 2 Actephila discoidea Heijkoop \& Welzen (Phyllanthaceae; formerly Euphorbiaceae). a. Habit, note the elongated leaf apices; b. fruit with thick nectar disc; c. apically split stigmas; d. widened seed (left, present when one ovule develops in a locule) and normal seed (right) (a-c: Takeuchi \& Towati 14639; d: Sands \& Jermy 1244; all L). - Drawing by Jan van Os, 2016. 


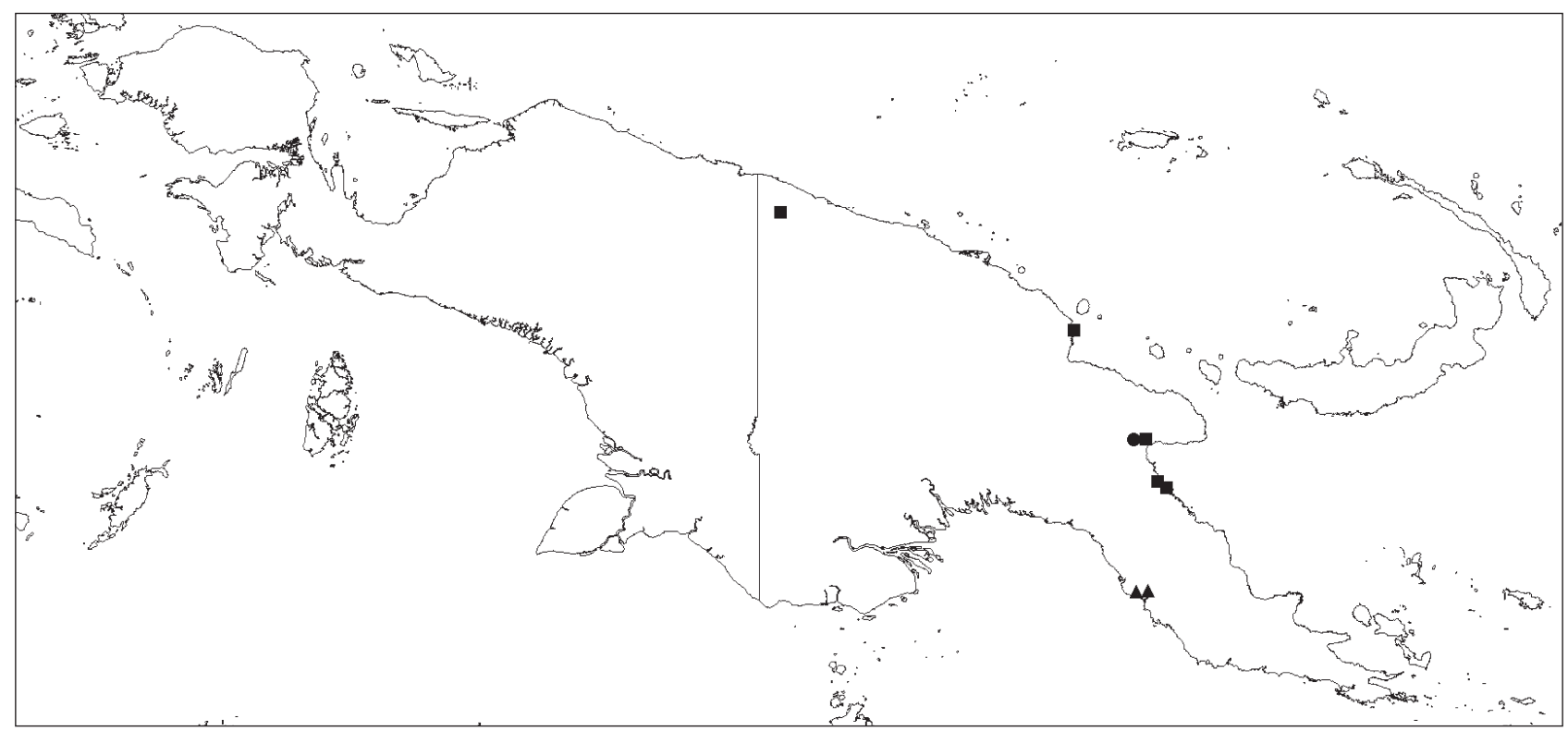

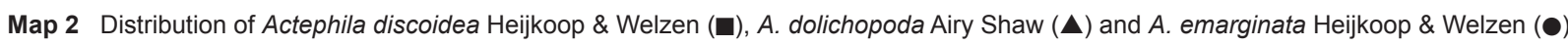

Note - Typical for the species are the leaves with an obtuse to acute base and a gradually tapering long apex; fruits on short, straight, sturdy pedicels; a thick, fleshy disc, visible after fruit dehiscence.

\section{Actephila dolichopoda Airy Shaw - Fig. 3; Map 2}

Actephila dolichopoda Airy Shaw (1978) 380; (1980a) 22. - Type: Carr 11774 (holo K; iso A, BM, L), Papua New Guinea, Kanosia.

Shrubs to trees, up to $5 \mathrm{~m}$ high; flowering branches 1-1.5 $\mathrm{mm}$ diam, covered with brown lenticels and hair stubbles. Indumentum: subglabrous with very short, papillae-like hairs on especially the younger branches, petioles, leaf blades; sericeous hairs on fruiting sepals. Stipules deltoid or broadly ovate to triangular or ovate, $0.8-1.6$ by $0.5-0.9 \mathrm{~mm}$, glabrous. Leaves: petioles $5-27(-37) \mathrm{mm}$ long, glabrous, pulvinate at both ends, pulvini becoming corky with age; blade elliptic to somewhat obovate, $7-16.3$ by $2.7-6.8 \mathrm{~cm}, 2.4-2.9$ times as long as wide, papyraceous, base acute, margin flat, apex acuminate to cuspidate, adaxially mid-green, abaxially paler mid-green, glabrous; nerves 10-11 per side. Flowers solitary. Staminate flowers not seen. Pistillate flowers not seen, observations from fruit: sepals obovate, widest just above the middle, c. 6 by $2.5 \mathrm{~mm}$, apex obtuse, outside somewhat sericeous; petals damaged; disc a distinct, thick, fleshy, wide ring, substantially covering the base of the sepals when fruiting. Fruits c. 1.8 $\mathrm{cm}$ diam, green; pedicels $27-85$ by $0.75-1(-2) \mathrm{mm}$, straight, often widening towards apex, glabrous; sepals not enlarging, reflexed, outside somewhat sericeous, glabrescent; wall with a very knobbly surface, c. $2 \mathrm{~mm}$ thick, glabrous; columella 9-13 $\mathrm{mm}$ long, basally completely covering disc. Seeds $12-13 \mathrm{~mm}$ long, 7-9.5 mm wide, $6-8 \mathrm{~mm}$ high, widened seeds c. $12 \mathrm{~mm}$ long, c. $11 \mathrm{~mm}$ wide, $6-7 \mathrm{~mm}$ high.

Distribution - Papua New Guinea (endemic in the Central Prov.).

Habitat \& Ecology — Lowland rain forest to (slightly deciduous) hill forest; soil: volcanic substrate. Altitude: sea-level up to $10 \mathrm{~m}$ (and likely higher). Flowering: April; fruiting: April, July.

Note - Typical for this species are the fruits on long, straight pedicels of up to $8.5 \mathrm{~cm}$ length. After dehiscence a fleshy nectar disc and a long columella, of up to $13 \mathrm{~mm}$ long, are visible with the columella extremely widening at the base completely covering the large disc. Further the fruit wall is somewhat thicker and more knobbly compared to the other species. Also remarkable are the branches covered with short, stiff, papillae-like hairs, while other Actephila species in this region either have short simple hairs or are glabrous on the branches. The stipules are on average short and narrow.

\section{Actephila emarginata Heijkoop \& Welzen, sp. nov. — Fig. 4;} Map 2

Resembles $A$. ovalis and $A$. trichogyna in having short often hairy petioles and a fleshy disc. However, $A$. ovalis has elongating sepals and $A$. trichogyna has much smaller leaves. Unique for this species is a somewhat emarginate leaf base. - Type: Brass 29350 (holo L), Papua New Guinea, Morobe District, Oomsis.

Shrubs, 1-2 m high, monocaulous or sparsely branched; flowering branches $2-4 \mathrm{~mm}$ diam, puberulous. Indumentum on most parts subglabrous. Stipules triangular to ovate, 1.4-1.7 by 1-1.2 mm, glabrous. Leaves: petioles 3-6 mm long, completely pulvinate, striate when dry, sometimes with corky edges, glabrous to densely puberulous; blade obovate, sometimes elliptic, $9.5-27$ by $4.6-10 \mathrm{~cm}, 1.6-2.7$ times as long as wide, papyraceous, base emarginate to sometimes more obtuse in a few leaves, margin flat, apex acuminate to cuspidate, adaxially dull, dark green, abaxially pale green, puberulous on midrib and venation (more so towards leaf base); nerves 8-13 per side. Flowers solitary, green. Staminate flowers not seen. Pistillate flowers not seen, data from fruit; sepals broadly ovate or ovoid, widest just below the middle to at base, $2-2.5$ by 1.5-2 mm, apex obtuse; petals not seen; disc a wide fleshy ring, substantially covering sepal base in fruit. Fruits $1.5-2 \mathrm{~cm}$ diam, green; pedicels $25-50$ by $0.5-1 \mathrm{~mm}$, thickening towards apex, smooth to edges somewhat striate when dry; sepals not elongating, horizontal to reflexed; wall with knobbly surface, lines of dehiscence not elevated, thin, glabrous; columella c. $6 \mathrm{~mm}$ long, basally completely covering the disc. Seeds immature flat, half-moon-shaped, c. $8 \mathrm{~mm}$ long, 1-2 $\mathrm{mm}$ wide, c. $5 \mathrm{~mm}$ high, mature not seen.

Distribution - New Guinea (only known from the type, endemic in area around Oomsis).

Habitat \& Ecology - Rain forest on flood bank of stream. Altitude: $100 \mathrm{~m}$. Flowering: May; fruiting: May.

Note - Typical for this species is the leaf base, which is generally emarginate, which do not occur in any of the other Actephila species in this region. The petioles are short and often strongly puberulous and the fruits have a relatively long, straight pedicel of up to $5 \mathrm{~cm}$ length. 


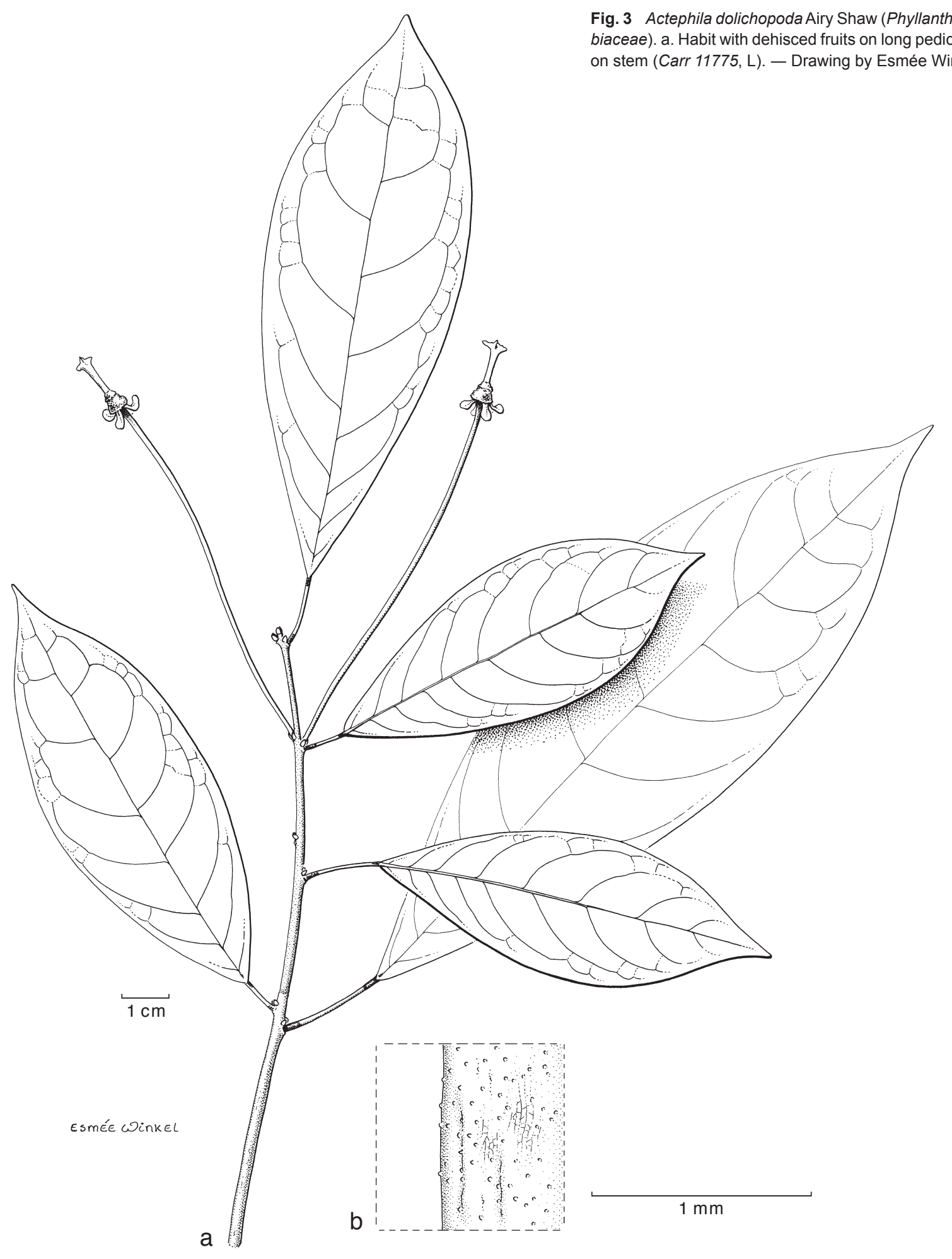

\section{Actephila excelsa (Dalzell) Müll.Arg. - Map 3}

Actephila excelsa (Dalzell) Müll.Arg. (1863) 78; (1866) 222; Hook.f. (1887) 282; Pax \& K.Hoffm. (1922) 191; Ridl. (1924) 196; Gagnep. (1927) 535; M.R.Hend. (1939) 68; Backer \& Bakh.f. (1963) 470; Airy Shaw (1972) 209; Whitmore (1973) 52; Airy Shaw (1975) 25; Chayam. (2005) 35, f. 5. - Anomospermum excelsum Dalzell (1851) 228. — Actephila excelsa (Dalzell) Müll.Arg. var. genuinum Pax \& K.Hoffm. (1922) 192, nom. inval. - Actephila excelsa (Dalzell) Müll.Arg. var. excelsa: Airy Shaw (1972) 209. — Type: Dalzell s.n. (holo K barcode K000186757), India, Syhadrensi?

[Croton laevigatum Wall. (1828) 7749 (non 7735), nom. nud., non Vahl] Savia actephila Hassk. (1844) 243; Baill. (1858) 571. — Actephila javanica Miq. (1859) 356; Müll.Arg. (1866) 222; J.J.Sm. (1910) 46; Ridl. (1924) 196; Backer \& Bakh.f. (1963) 470; Airy Shaw (1980a) 22; (1982) 4; Chayam. (2005) 38, f. 6. - Actephila excelsa (Dalzell) Müll.Arg. var. javanica (Miq.) Pax \& K.Hoffm. (1922) 192; Merr. (1923) 390; (1929) 139; Airy Shaw (1972)
209; Whitmore (1973) 52; Airy Shaw (1975) 25; (1980a) 22; (1981) 248 (1983) 3. - Lectotype (designated here): Blume 1670 (L), Java. Actephila neilgherrensis Wight (1852) 29, t. 1910. - Type: Wight KD 2574 (K), [India,] Neilgherries, Coonoor.

[Savia zeylanica Baill. (1858) 571, nom. nud. -] Actephila zeylanica Baill. ex Müll.Arg. (1863) 77; (1866) 221. - Actephila excelsa (Dalzell) Müll.Arg. var. zeylanica (Baill. ex Müll.Arg.) Pax \& K.Hoffm. (1922) 192. - Type: Thwaites 2532 (G-DC, P 4 sheets), Ceylon (= Sri Lanka).

Actephila bantamensis Miq. (1859) 356. - Syntypes: Hasskarl s.n. (perhaps U fragment), [Indonesia,] Java; Zollinger 1662 (G-DC, P 2 sheets, fragment U?), [Indonesia,] Java, Zuid Bantam (S Bantam).

Actephila major Müll.Arg. (1863) 77; (1866) 221. - Type: Zollinger 512 (holo B lost; iso perhaps fragment in G-DC as Zollinger s.n.), [Indonesia,] Java Actephila thomsonii Müll.Arg. (1865) 65; (1866) 222. - Actephila excelsa (Dalzell) Müll.Arg. var. thomsonii (Müll.Arg.) Pax \& K.Hoffm. (1922) 192. — Type: G. Thomson s.n. (not located), India, Maisor \& Carnatic. 
Fig. 4 Actephila emarginata Heijkoop \& Welzen (Phyllanthaceae; formerly Euphorbiaceae). Habit with typical emarginate bases of the leaf blades (L.J. Brass 29350, L). - Drawing by Jan van Os, 2016.

Actephila gigantifolia Koord. (1897) 579, 625 (description); Pax \& K.Hoffm. (1922) 194. - Type: Koorders 16937 (holo L), [Indonesia,] Celebes, bivak Totok.

Actephila minahassae Koord. (1897) 579, 625 (description); Pax \& K.Hoffm. (1922) 195. - Type: Koorders s.n. (not found), [Indonesia,] Celebes, Ratahan.

Pimeleodendron dispersum Elmer (1908) 308 ('dispersa'); Pax \& K.Hoffm. (1912) 56 (excluded species). — Actephila dispersa (Elmer) Merr. (1909) 276. - Type: Elmer 7245 (holo PNH lost; iso K 2 sheets, L), Philippines, Leyte, Palo.

Actephila gitingensis Elmer (1910) 903; Airy Shaw (1975) 25; (1983) 3. Type: Elmer 12141 (holo PNH lost; iso A, E, G, GH, HBG, K, L, MO, US), Philippines, Sibuyan Island, Cadiz Prov., Magallanes (Mt Giting-Giting).

Actephila magnifolia Elmer (1910) 903; Merr. (1923) 390; Pax \& K.Hoffm. (1922) 193; Airy Shaw (1983) 3 - Type: Elmer 12303 (holo PNH lost; iso A, E, G, HBG, K, L, MO, US), Philippines, Sibuyan Island, Cadiz Prov., Magallanes (Mt Giting-Giting).

Actephila dolichantha Croizat (1942) 30. - Type: C.W. Wang 79253 (holo A, not seen), China, Yunnan, Kuen-ger, Che-li Hsien (for inclusion under A. excelsa see Govaerts et al. 2000).

Actephila excelsa (Dalzell) Müll.Arg. var. brevifolia N.Balach., Mahesw. \& Chakrab. (2009) 717, f. 1. - Type: B. Maheswaran 990 A (holo AURO, not seen; iso AURO, not seen), India, Andamans, North Andaman Island, Saddle Peak. See note 3.

Shrubs to tree(let)s, up to $10(-15) \mathrm{m}$ high, dbh up to $30 \mathrm{~cm}$; flowering branches $2-9$ (-20 when rami- or cauliflorous) $\mathrm{mm}$ diam, with (light) brown lenticels, glabrous to puberulous, more puberulous towards apex. Outer bark pale tan to greyish to greenish yellow to reddish, smooth to with fine vertical fissures to scaly; inner bark green to khaki-green to yellow; sapwood white to pale orange. Indumentum: most parts subglabrous to somewhat hairy. Stipules triangular or ovate to deltoid or broadly ovate, $(1-) 1.5-3(-3.5)$ by $1-2 \mathrm{~mm}$, slightly sericeous outside to often glabrous. Leaves alternate to subopposite at branch ends; petioles 5-95 mm long, glabrous to slightly to completely puberulous, brown, pulvinate at both ends, pulvini becoming corky with age; blade elliptic (to \pm obovate), (4-)5.535.5 by $(1.1-) 1.9-13.5(-15.9) \mathrm{cm}, 1.9-3.6(-8)$ times as long as wide, papyraceous to pergamentaceous, base acute to obtuse, margin flat, apex cuspidate (to acuminate or rarely acute), adaxially glossy, light to dark green, abaxially paler green than adaxially, sometimes somewhat puberulous on midrib and secondary venation, more so towards base; nerves (5-)7-16 per side. Flowers solitary to fascicled, staminate ones often cauliflorous or ramiflorous, pistillate ones axillary, on brachyblasts after several seasons (up to $2 \mathrm{~cm}$ diam on thick branches); pedicels green, widening towards apex, glabrous to sericeous; sepals light green to white (with pink base), margin sometimes slightly membranous, apex acute to obtuse; petals: apex truncate to obtuse or rounded, erose, white to greenish white; disc a narrow thin ring, light yellow. Staminate flowers $2-3 \mathrm{~mm}$ diam; pedicels c. $2 \mathrm{~mm}$ long; sepals ovate to elliptic to diamond shaped, widest just below to in the middle, $1.3-2$ by $1.2-2$ $\mathrm{mm}$, green to light green; petals $1-2$ by $0.8-1 \mathrm{~mm}$; stamens free, greenish to white, anthers (light) yellow. Pistillate flowers 3-5 mm diam, white to greenish; pedicel 8-31(-53) mm long; sepals ovate to elliptic to somewhat diamond shaped to obovate, widest just below to just above the middle, (1.5-)2-4(-5) by (1-)1.5-3(-3.5) $\mathrm{mm}$, green to greenish white; petals $(0.6-)$ $0.7-2$ by $(0.3-) 0.5-1.3 \mathrm{~mm}$, sometimes somewhat split into 


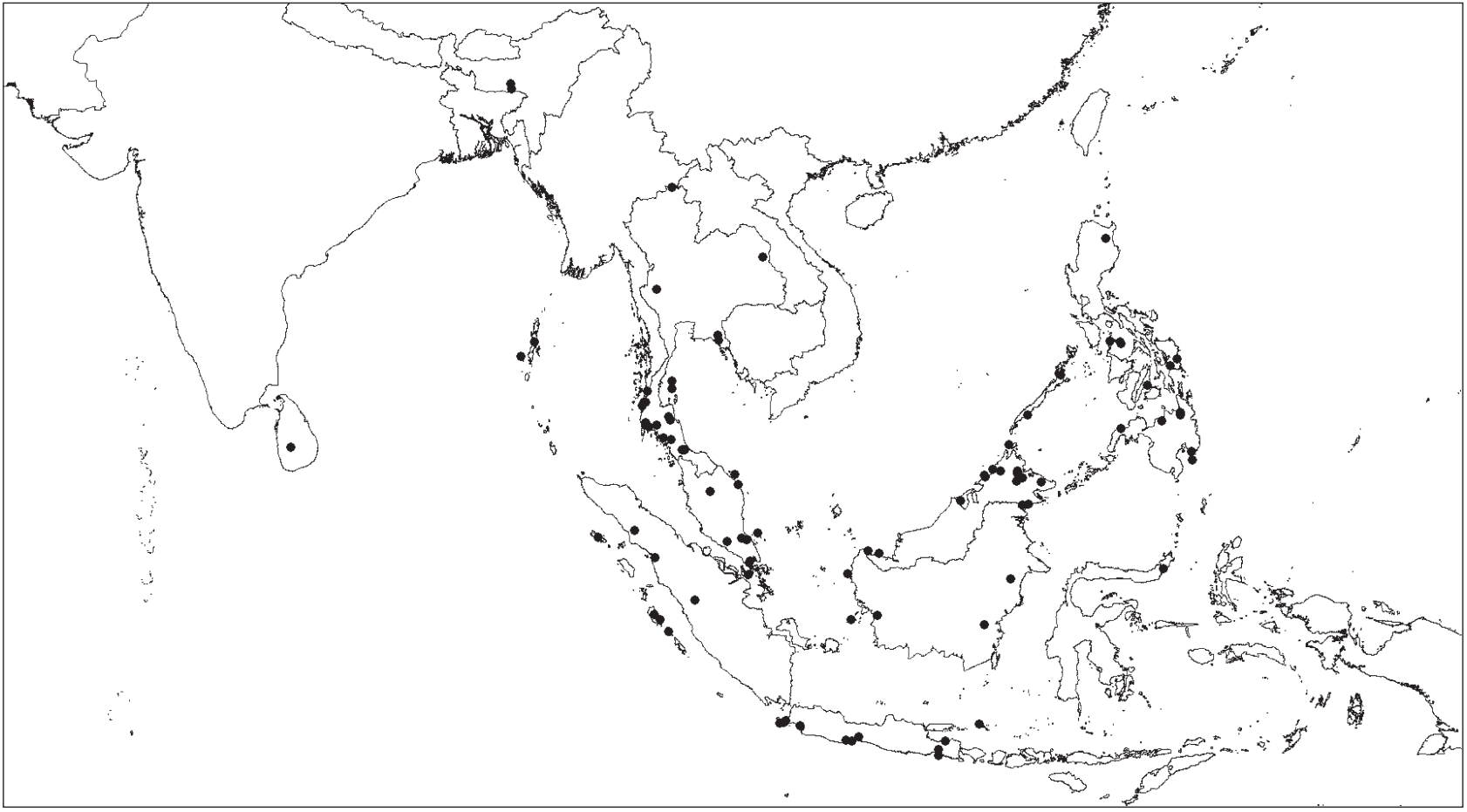

Map 3 Distribution of Actephila excelsa (Dalzell) Müll.Arg.

two; disc slightly covering base of sepals in fruit; ovary $0.8-2.5$ by $0.9-3 \mathrm{~mm}$, green to green-white, glabrous, stigmas $0.4-0.6$ $\mathrm{mm}$ long, basally pinkish, apically light green. Fruits $1.3-2 \mathrm{~cm}$ diam, pendent, green (immature) to brown (mature); pedicels elongating up to $75 \mathrm{~mm}$ long, (0.4-)0.7-1.5 mm diam, often curved, glabrous (to slightly sericeous), somewhat striate when dry; sepals not elongating, reflexed to flat when dry, dark green, outside sometimes slightly sericeous, often glabrous; fruit wall somewhat knobbly, lines of dehiscence sometimes slightly elevated, thin, glabrous (to slightly sericeous); columella 5-8 $\mathrm{mm}$ long, basally somewhat thickened but not completely covering disc and base of sepals, fibrous after dehiscence. Seeds 7-12 $\mathrm{mm}$ long, 5-10 $\mathrm{mm}$ wide, 5-9 $\mathrm{mm}$ high, widened seeds (7-)8-13 mm long, (6.5-)9-11(-14) mm wide, 5-8(-9) mm high.

Distribution — India, Sri Lanka, Myanmar, S China, Thailand, Indochina, Malay Peninsula, Sumatra, Java, Borneo, the Philippines, Sulawesi.

Habitat \& Ecology - Primary mixed lowland dipterocarp rain forest, evergreen forest, transition to deciduous forest, secondary forest, hill forest, kerangas forest, along rocky seashores, rivers and roads. Soil: limestone, loam, sandy soil, ultrabasic, sandy clay, granite-derived, basalt. Altitude: sealevel to $500(-1350) \mathrm{m}$. Flowering and fruiting: the whole year through.

Vernacular names - Malay Peninsula: Kelapa Tupai. Sumatra: Baner etem, Pehailigei, Toetoeg getah. Philippines: Manikusan.

Notes - 1. A highly variable species, which greatly varies in leaf size and petiole length. Leaf blade shapes vary from elliptic to somewhat ovate or obovate, apices vary from acute to cuspidate. Fruiting pedicels are usually around $2-3 \mathrm{~cm}$ long, curved and widening towards apex, but longer pedicels are observed losing their curved shape. The indumentum varies from almost completely absent to being heavily puberulous on most parts. Various groups of specimens have somewhat distinct characters:

a. The northern latitudes ( $N$ \& SW Thailand) and the specimens in the western part of the distribution (India, Sri Lanka) have generally smaller leaves and short petioles (formerly var. excelsa; Chayamarit 2005), while in most of Malesia, but also S Thailand, the petioles are long(er) and the leaf blades can be quite large (see also under f; formerly var. javanica; Chayamarit 2005), but small blades are also found throughout the distribution (see under b).

b. Forbes 3112a, Korthals s.n., SAN (Sugau \& Diwol) 141043, SAN (Maikin, Donggop \& Francis) 130671, BRUN (Salleh Ismail) 16862, PPI (Stone, Reynoso \& Fernando) 6964, de Vogel 2771, University of San Carlos 98 have small leaf blades, $5.5-14.5$ by $1.9-5.8 \mathrm{~cm}$ and short petioles, $0.4-2.7$ $\mathrm{cm}$ long. The samples are found in the eastern part of the species distribution: Sumatra, Java, Borneo and the Philippines. PPI 6964 (Philippines) is also special because of the somewhat elevated reticulate lines on the outside of the fruit wall, instead of the usual knobbly surface.

c. KEP FRI (Loh) 19212 (Malay Peninsula) has very narrow leaves, up to 8 times longer than wide, also the fruits seem slightly smaller and the seeds are below average size. The plant is growing near a waterfall, which may cause the slightly different appearance.

d. Koorders 26891 and 30269 have long fruiting pedicels, 6-7.5 cm long, 4-7 cm in Koorders 39682, while Koorders 2738 has flowering pedicels of c. $5.3 \mathrm{~cm}$ long. All specimens are from Java. No other specimens have fruiting pedicels exceeding $5.5 \mathrm{~cm}$. The petioles are relatively short for the species with a general length of $7-28 \mathrm{~mm}$. However, the leaf blade sizes of $10-25$ by $4.5-9 \mathrm{~cm}$ typically fit in with the rest of the specimens.

e. Afriastini 1243, Rappard 168 and Backer 36980, all from Java, show somewhat smaller stipules, petioles and leaf blades: Stipules sizes vary between $0.8-1.2$ by $1-1.2 \mathrm{~mm}$, petiole length $2-18 \mathrm{~mm}$ long, and leaf blade sizes of $4-14.5$ by $2-5.5 \mathrm{~cm}$, which are $2-2.7$ times as long as wide. Apices vary between acute and acuminate, never extending up to cuspidate.

f. The types of $A$. gigantifolia, Koorders 16937 (Sulawesi), and A. magnifolia, Elmer 12303 (Philippines), show enormous leaf blades, up to 35 by $17 \mathrm{~cm}$, much larger than all other specimens of Actephila. However, the specimens still show the typical bend in the upper pulvinus. 
2. Actephila puberula, from the Andaman islands, has often been treated as synonym of $A$. excelsa, but the leaf base is emarginate to rounded instead of obtuse to acute and the ovary is densely hairy instead of glabrous. Therefore, A. puberula (with A. excelsa var. puberula (Kurz) Pax \& K.Hoffm. as synonym) is here considered to be a distinct species. The fruits of A. puberula can be up to $2.5 \mathrm{~cm}$ diam (instead of up to $2 \mathrm{~cm}$ ) and the surface is more knobbly than in $A$. excelsa.

3. Actephila excelsa var. brevifolia is added to the synonymy, because it has the typical leaf base of $A$. excelsa and does not really differ the description above other than sometimes slightly smaller leaf blades (with consequently slightly fewer secondary nerves).

\section{Actephila latifolia Benth. - Map 4}

Actephila latifolia Benth. (1873) 89; F.M.Bailey (1902) 1414; Pax \& K.Hoffm. (1922) 194; Airy Shaw (1980c) 587; (1982) 4; P.I.Forst. (2005) 74, f. 5. Lectotype (designated by Airy Shaw 1980c): Daemel s.n. (holo K, photo BRI), Australia, Queensland, Cape York; other former syntype: Dallachy s.n. (not seen), [Australia,] Queensland, Rockingham Bay.

Shrubs to tree(let)s, up to $5 \mathrm{~m}$ high, dbh up to $5 \mathrm{~cm}$; flowering branches 1-3 mm diam, with few brown lenticels, somewhat sericeous at tips. Bark nondescript; blaze thick, pinkish red; wood dense, cream-yellow. Indumentum: subglabrous on branches, brachyblasts and sepals. Stipules deltoid to broadly ovate, $0.8-1.3$ by $0.8-1.3 \mathrm{~mm}$, glabrous, often somewhat folded horizontally. Leaves alternate to subopposite at branch ends; petioles 3-22 mm long, glabrous, completely pulvinate to pulvinate at both ends; blade $6.5-14.9$ by $3.2-6.9 \mathrm{~cm}$, $1.9-2.4(-3)$ times as long as wide, pergamentaceous, base slightly attenuate to acute, margin flat, apex obtuse to acute to slightly acuminate, abaxially glabrous; nerves 7-10 per side. Flowers white to cream-yellow, solitary to paired or fascicled, on older branches on small brachyblasts; pedicels not widening towards apex, glabrous; sepals: apex rounded or somewhat obtuse; petals: apex rounded, not erose; disc a thick, fleshy, wide ring. Staminate flowers c. $4 \mathrm{~mm}$ diam; pedicels c. $7 \mathrm{~mm}$ long; sepals ovate to elliptic, c. 2.8 by $1.8 \mathrm{~mm}$, margin slightly membranous; petals c. 1 by $0.5 \mathrm{~mm}$; disc hanging over the base of the sepals; stamens: filaments c. $2 \mathrm{~mm}$ long. Pistillate flowers c. $4 \mathrm{~mm}$ diam; pedicel $6-35 \mathrm{~mm}$ long; sepals ovate to elliptic to obovate, widest just below to in the middle, $2-3.3$ by $1-3.3 \mathrm{~mm}$; petals c. 1.2 by $0.6 \mathrm{~mm}$; disc pale yellow, substantially covering base of sepals in fruit; ovary c. 0.8 by $1-1.4 \mathrm{~mm}$, glabrous, stigmas $0.8-2 \mathrm{~mm}$ long. Fruits c. $10 \mathrm{~mm}$ diam, green; pedicels $15-35$ by $0.7-0.8 \mathrm{~mm}$, barely widening towards apex, glabrous, smooth to striate when dry; sepals slightly enlarging, $4.5-5(-5.5)$ by $2.5-4.5(-5) \mathrm{mm}$, glabrous on both sides, reflexed; wall with knobbly surface, thin, glabrous; columella $6-8 \mathrm{~mm}$ long. Seeds c. $8.5 \mathrm{~mm}$ long, c. $7 \mathrm{~mm}$ wide, c. $7 \mathrm{~mm}$ high; widened seeds not seen.

Distribution - Moluccas (Aru IsI.), Lesser Sunda Islands (Tanimbar, Timor), Australia (Queensland).

Habitat \& Ecology - Riverine to rain forest bordering savannah, semi-deciduous to complex notophyll vine-forest. Soil: sand, granite. Altitude: $10-480 \mathrm{~m}$. Flowering: January; fruiting: March-May, October.

Vernacular name - Aru Islands (P. Trangan): Balabal.

Note - Typical for this species are the small deltoid stipules, which often have a horizontal fold in the middle. The petioles are short, the leaf blades are relatively constant in size and generally up to 15 by $7 \mathrm{~cm}$ with an acute or obtuse apex. The calyx slightly enlarges in fruit to generally c. 5 by $4 \mathrm{~mm}$. The persistent disc is wide, thick and fleshy, covering the base of the sepals. The septa often look weak and thin, not as sturdy as in other species, however, this may be due to underdevelopment.

\section{Actephila lindleyi (Steud.) Airy Shaw - Fig. 5; Map 4}

Actephila lindleyi (Steud.) Airy Shaw (1971) 496; (1980a) 23; (1980c) 587; (1982) 4; N.C.W.Beadle, O.D.Evans \& Carolin (1982) 351; P.I.Forst. (2005) 75, f. 6. - Securinega nitida W.T.Aiton [(1813) 383, nom. nud.] ex Lindl. (1821) t. 9 (non Willd.; see De Jussieu (1824) 14, in obs.). - Lithoxylon lindleyi Steud. (1841) 57, pro nom. nov. - Lithoxylon nitidum (W.T.Aiton ex Lindl.) Baill. (1858) 590, nom. illeg., superfl.; Müll.Arg. (1866) 232; Nadeaud (1873) 72. - Actephila nitida (W.T.Aiton ex Lindl.) Benth. \& Hook.f. ex Drake (1892) 286, nom. illeg.; (1893) 177; Pax \& K.Hoffm. (1922) 194. - Type: cult. in Hort. Kew., 1813-1821 (holo K, photo BRI), native of Otaheite [= Tahiti].

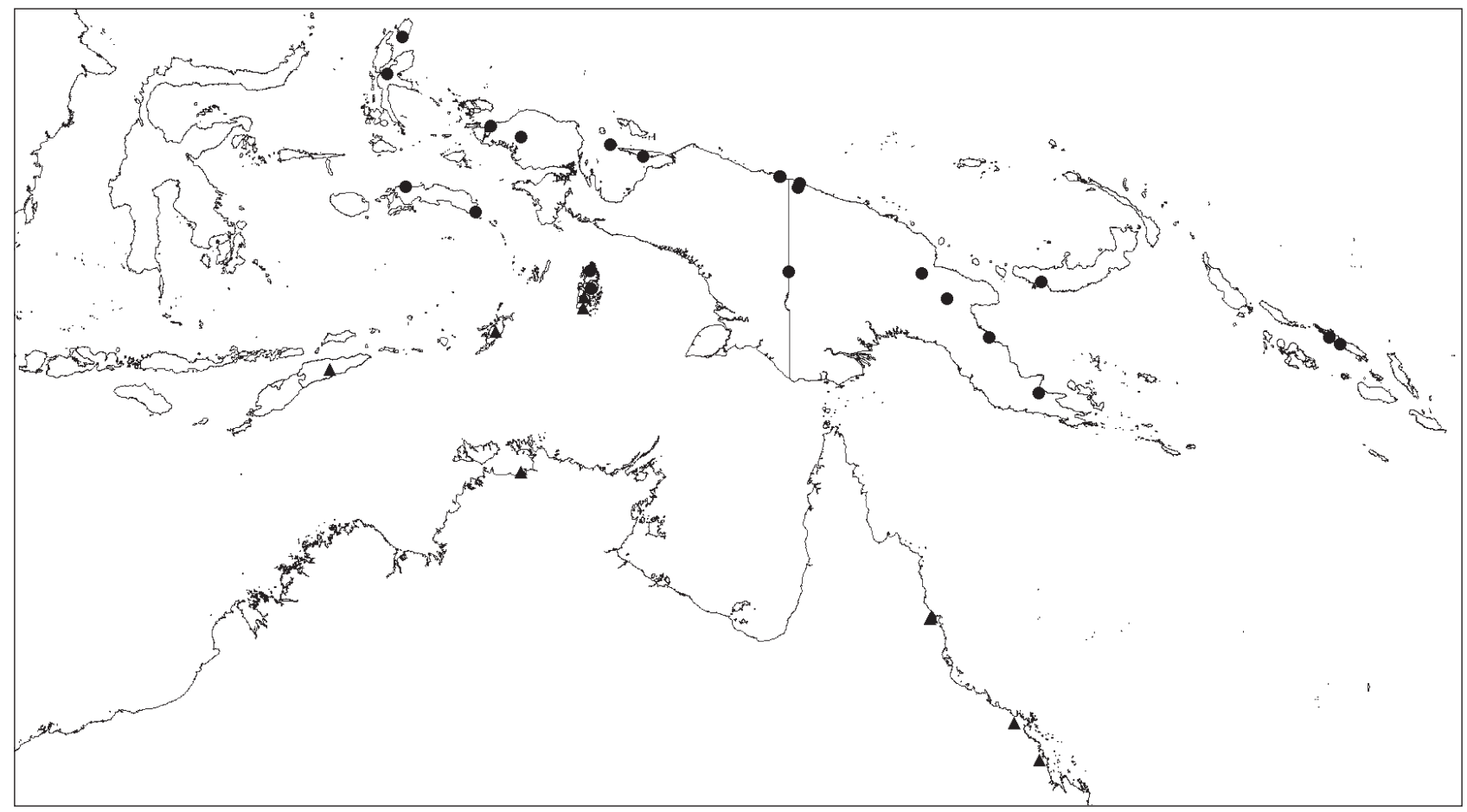

Map 4 Distribution of Actephila latifolia Benth. (A) and A. lindleyi (Steud.) Airy Shaw (0). 
Lithoxylon grandifolium Müll.Arg. (1865) 65; (1866) 232. - Actephila grandifolia (Müll.Arg.) Baill. (1866) 330, 360, t. 10; Benth. (1873) 89; F.M.Bailey (1902) 1413; Pax \& K.Hoffm. (1922) 193; R.H.Anderson (1968) 218, 377; N.C.W.Beadle, O.D.Evans \& Carolin (1972) 252; P.I.Forst. (2005) 71, f. 4. - Type: F. Mueller s.n. (holo G-DC, BRI photo), [Australia, New South Wales,] Clarence River.

(Woody) herbs to shrubs to small trees, up to $9 \mathrm{~m}$ high, at least up to $10 \mathrm{~cm}$ diam; flowering branches $2-5 \mathrm{~mm}$ diam, glabrous to slightly sericeous at tip. Outer bark grey-brown to brown, smooth, with many, large, brownish, often somewhat raised lenticels to shallowly longitudinally fissured; blaze white; inner bark reddish brown, no exudate; wood cream to pale orange. Indumentum: most parts subglabrous. Stipules deltoid or broadly ovate to triangular or ovate, $1.2-3(-4)$ by $1-2 \mathrm{~mm}$, straight, glabrous. Leaves alternate to almost opposite at end of branches; petioles $0.1-2.7 \mathrm{~cm}$ long, completely pulvinate, apex sometimes gradually tapering into base of blade, often with corky edges when older, often glabrous, sometimes slightly sericeous; blade elliptic to narrowly elliptic to sometimes somewhat obovate, $7.5-25(-30)$ by $(2-) 2.5-11 \mathrm{~cm}, 1.7-4.8(-6.7)$ times as long as wide, papyraceous to pergamentaceous, base usually attenuate to rarely slightly more acute, margin flat, apex acute or somewhat obtuse to acuminate or cuspidate, adaxially dull to glossy green to dark green, abaxially lighter green than above, glabrous; nerves 7-14(-18) per side. Flowers often solitary to paired or fascicled, on brachyblasts when older, greenwhite to white; pedicels not widening towards apex, often glabrous, sometimes slightly sericeous; sepals: apex acute

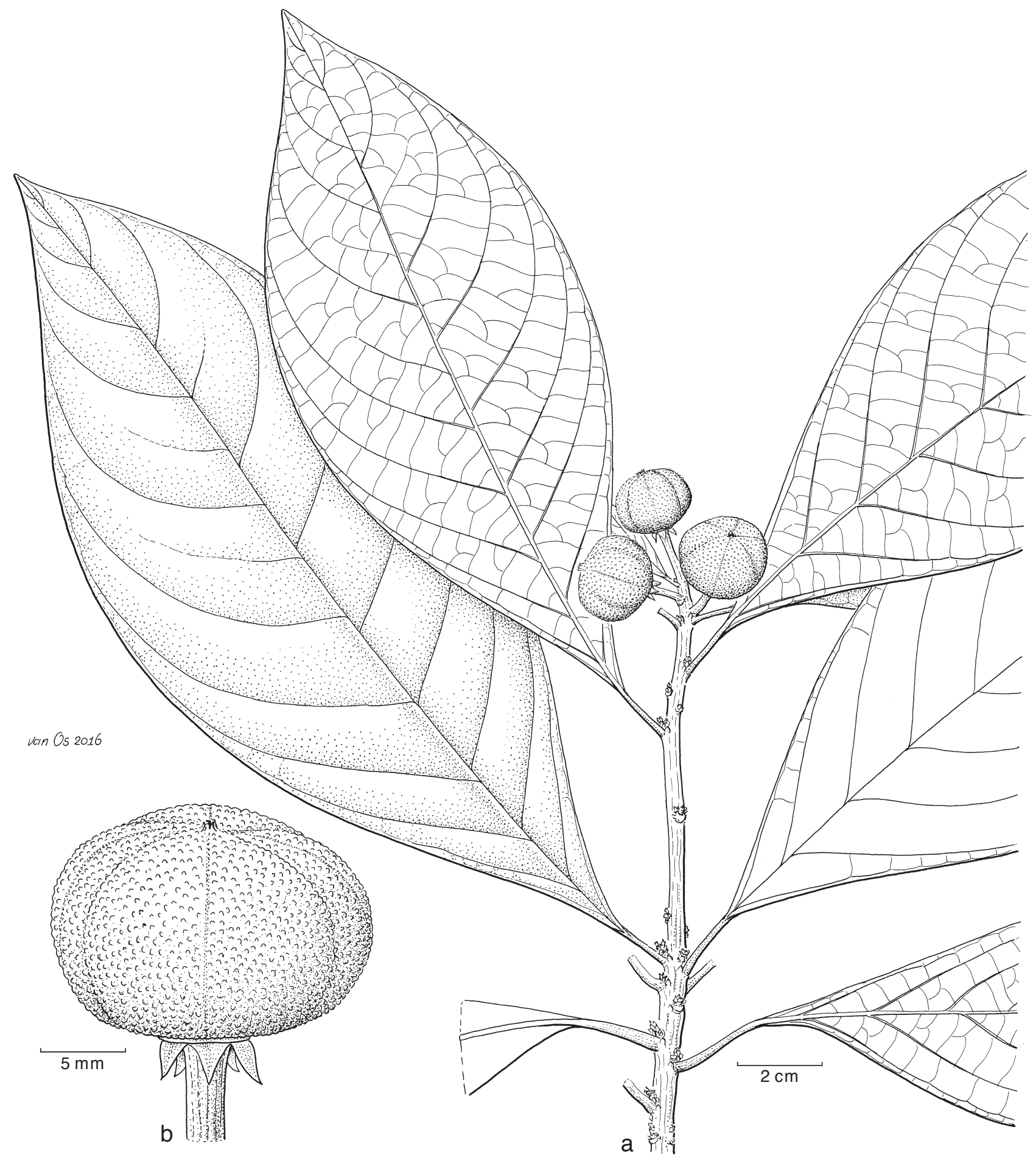

Fig. 5 Actephila lindleyi (Steud.) Airy Shaw (Phyllanthaceae; formerly Euphorbiaceae). a. Habit; b. fruit with thin disc (Kato, Ueda, Okamoto, Akiyama, Sunarno \& Mahjar C-7094, L). - Drawing by Jan van Os, 2016. 
to obtuse; petals: apex truncate to rounded, erose; disc a thin narrow papery ring. Staminate flowers c. $3 \mathrm{~mm}$ diam, green to white with purple tinge; pedicel $3-4 \mathrm{~mm}$ long; sepals ovate, widest just below the middle, c. 2 by $1.5 \mathrm{~mm}$, margin membranous; petals c. 1 by $0.5 \mathrm{~mm}$; disc folded upwards at the edges; stamens: filaments c. $1.3 \mathrm{~mm}$ long, connate at base; small pistillode on staminal tube. Pistillate flowers c. $4 \mathrm{~mm}$ diam, white; pedicel c. $3 \mathrm{~mm}$ long; sepals broadly ovate or deltoid to ovate to elliptic, $1.3-2.5(-3)$ by $1.3-2(-2.5) \mathrm{mm}$, widest at base to in the middle; petals c. $0.7-1$ by $0.25-0.5 \mathrm{~mm}$; disc slightly covering the base of sepals in fruit; ovary c. 1 by $0.8-1.5 \mathrm{~mm}$, glabrous, stigmas $0.4-0.6 \mathrm{~mm}$ long. Fruits immature globose, mature subglobose, 1-2 cm diam, light green (immature) to brownish green to red; pedicels $6-15(-40)$ by (0.5-)0.9-2(-2.5) $\mathrm{mm}$, straight, sometimes with transverse small grooves, edges smooth to somewhat striate when dry, sometimes somewhat corky, glabrous; sepals not enlarging, completely glabrous, reflexed; wall with knobbly surface, thin, glabrous, lines of dehiscence not elevated; columella 5-8 $\mathrm{mm}$ long, fibrous after dehiscence. Seeds 7.5-10 mm long, (5-)6-8 $\mathrm{mm}$ wide, $4.5-6.5 \mathrm{~mm}$ high, widened seeds $7-8 \mathrm{~mm}$ long, $7-8$ $\mathrm{mm}$ wide, 4-5 $\mathrm{mm}$ high.

Distribution - Moluccas, New Guinea (incl. Aru Islands and New Britain), Solomon Islands (Santa Ysabel).

Habitat \& Ecology - Primary lowland rain forest, riverine forest, Castanopsis-oak forest, old secondary forest, along rivers and sago swamps. Soil: (sandy) clay to limestone or coral sand. Altitude: sea-level to $580(-1370) \mathrm{m}$. Flowering: February-August, November; fruiting: January-October.

Vernacular names - Aru Islands (Pulau Kobroor): Ay, Ay kway ngom. New Guinea: Papua: Krokaan (Maibrat); New Britain: Ugunape. Solomon Islands (Santa Ysabel): Susui.

Notes -1 . The leaves in this species are highly variable, they range from short to long, narrow to wide, apices range between acute and cuspidate. However, the attenuate leaf blade base is constant (almost unique to this species, with the exceptions of $A$. ovalis and $A$. latifolia). Typical are the short petioles and short and somewhat sturdy, straight fruiting pedicels.

Exceptional forms are:

- Specimens from Indonesian Papua tend to have narrower leaves, Van Royen 5296 being narrowest, with leaf blades up to 6.7 times as long as wide. Also exceptional are the subterminal fascicles of relatively small fruits. Aet \& Idjan 342 (1939) also has a very narrow base which gradually merges into the petiole, and the apex is gradually tapering into a widely cuspidate apex (latter also in BW (Van der Sijde) 4161). Brass 32390 was collected at the exceptionally high altitude of $1370 \mathrm{~m}$; it only deviates from other specimens in the leaf blades with an obtuse to somewhat acute apex.

- Several specimens have long petioles and/or pedicels. NGF (Frodin) 26551 has long pedicels (c. $4 \mathrm{~cm}$ long), but also somewhat longer petioles (up to $2 \mathrm{~cm}$ long). LAE (Wiakabu et al.) 50086 deviates in longer petioles (12-27 mm long), longer fruiting pedicels (c. $23 \mathrm{~mm}$ long) and an obtuse to acute leaf blade base (instead of attenuate). NGF (Katik) 46983 also has much longer petioles (25-48 mm long) and longer fruiting pedicels (c. $26 \mathrm{~mm}$ long), which are somewhat widening towards the apex. Also exceptional is the presence of indumentum (other $A$. lindleyi are subglabrous), especially the moderate indumentum on the petioles is unique.

2. Actephila mooreana is to be recognized as an accepted species and not a synonym of $A$. lindleyi. The latter species does not occur in Australia and differs in the characters leaf apex, leaf size, leaf margin, size of the disc, and pistillode. Leaf blades of $A$. mooreana are up to $17 \mathrm{~cm}$ long (often below
$10 \mathrm{~cm}$ ), with an acute to rounded apex and a wavy margin. The pistillode in the staminate flowers of $A$. mooreana is hairy. The disc in $A$. mooreana is wide and fleshy in staminate and pistillate flowers, pushing the sepals backwards in fruit. Fruits of $A$. mooreana are up to $1.3 \mathrm{~cm}$ diam. Actephila mooriana, the original spelling by Baillon (1866) was incorrect.

\section{Actephila ovalis (Ridl.) Gage - Fig. 6; Map 5}

Actephila ovalis (Ridl.) Gage (1922) 219; Ridl. (1924) 196; Gage (1936) 519; M.R.Hend. (1939) 68; Smitinand (1962) 139; Airy Shaw (1972) 210; Whitmore (1973) 51; Chayam. (2005) 38, f. 7, pl. II: 1. - Dimorphocalyx ovalis Ridl. (1911) 178; Smitinand (1961) 52, photo. - Syntypes: Curtis s.n. (SING), Malaysia, Lankawi, Kwah; Ridley 14890 (K 2 sheets, SING), Malaysia, Perlis woods at Bukit Telor Jambu, Kanga.

(Sub)shrubs to small trees, up to $5 \mathrm{~m}$ high, stem brown; flowering branches 1-4 mm diam, with brown to whitish lenticels, puberulous. Indumentum of simple hairs, most parts subglabrous. Stipules narrowly ovate to narrowly triangular, 1.5-4 by $0.8-1.5 \mathrm{~mm}$, outside strongly sericeous when young, often glabrous. Leaves alternate to subopposite; petioles 2-6(-13) $\mathrm{mm}$ long, completely pulvinate, strongly puberulous; blade elliptic, $6.4-15.4$ by $2.1-4.9 \mathrm{~cm}, 2.7-3.8(-4.4)$ times as long as wide, papyraceous, base attenuate to acute, margin wavy, apex narrowly to widely cuspidate, sometimes more acuminate, adaxially mid to dark green, abaxially slightly lighter green, sometimes somewhat puberulous basally on midrib; nerves 10-17 per side. Flowers solitary, on older branches on small brachyblasts; petals: apex truncate to rounded, erose; disc a thick fleshy ring. Staminate flowers c. $5 \mathrm{~mm}$ diam; pedicel 2-4 mm long, widening towards apex, glabrous to sericeous, cream-coloured; sepals ovate, widest just below the middle, c. 2 by $1.2-1.5(-2) \mathrm{mm}$, light greenish to cream, margin slightly membranous, apex rounded or somewhat obtuse, outside hairy; petals c. 2 by $0.9 \mathrm{~mm}$, white; disc covering base of sepals, whitish; anthers yellow to orangish; pistillode small. Pistillate flowers green; sepals: lobes obovate, 2 smaller, c. 3.5 by $3 \mathrm{~mm}$, 3 larger obovate, c. 5 by $4.5 \mathrm{~mm}$, enlarging in fruit, green; petals $1.4-1.5$ by $0.5-0.7 \mathrm{~mm}$; disc substantially covering sepal base

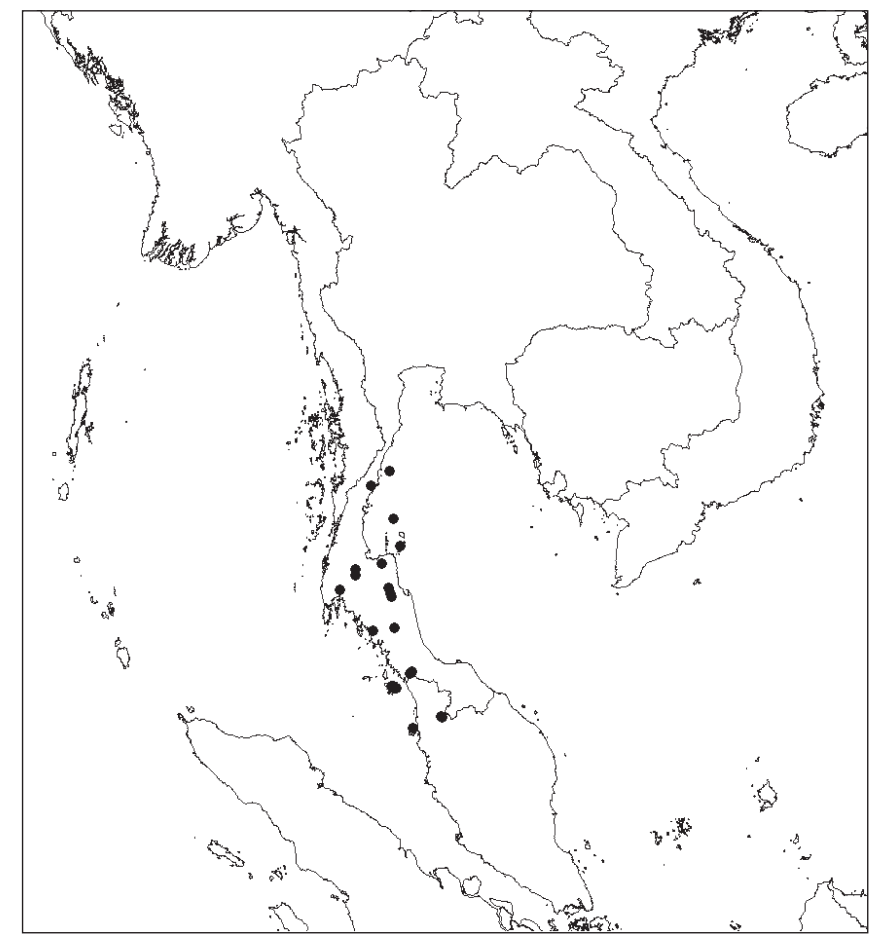

Map 5 Distribution of Actephila ovalis (Ridl.) Gage. 


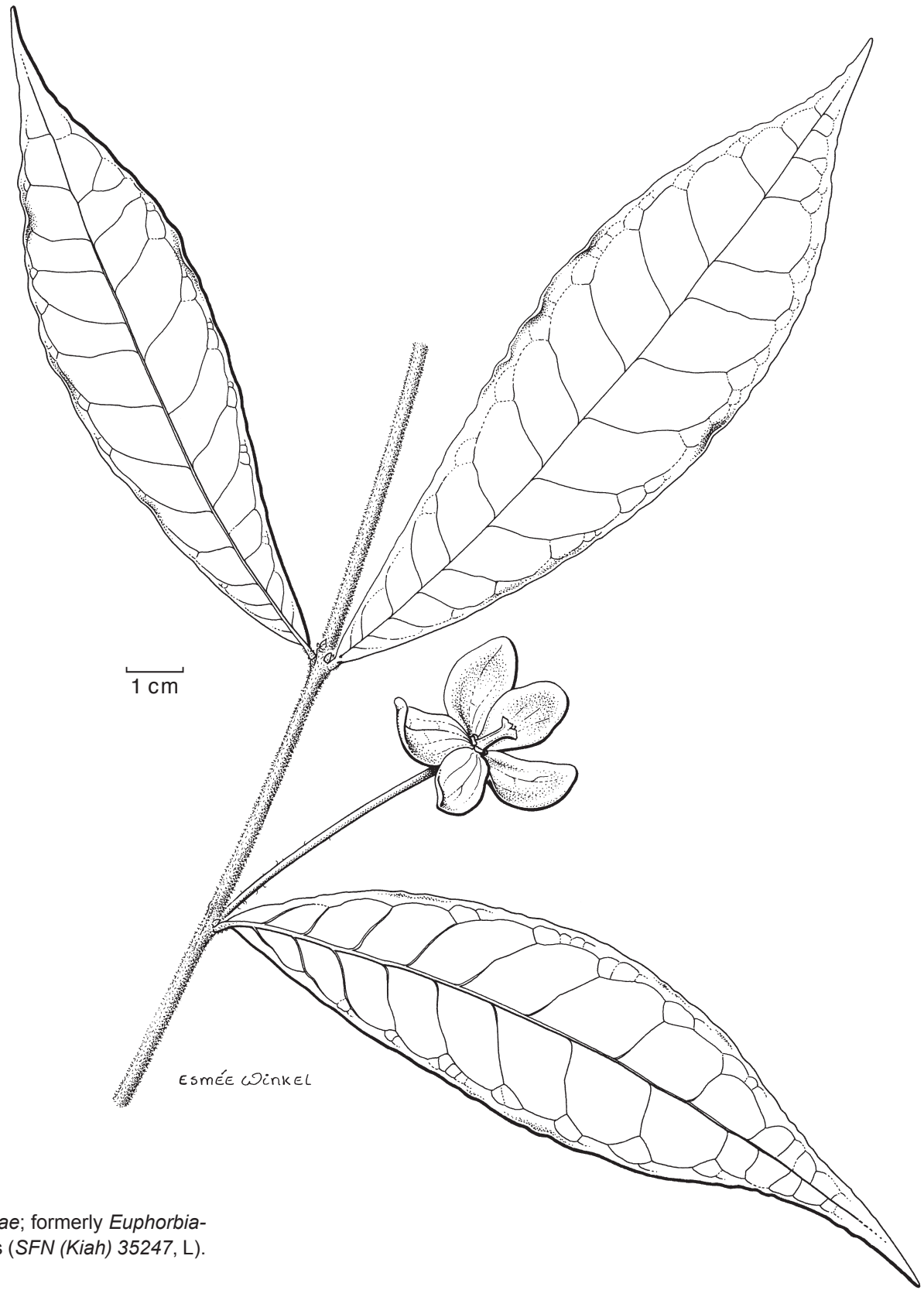

Fig. 6 Actephila ovalis (Ridl.) Gage (Phyllanthaceae; formerly Euphorbiaceae). Habit with dehisced fruit and enlarged sepals (SFN (Kiah) 35247 , L). — Drawing by Esmée Winkel, 2016.

in fruit; ovary ovoid, slightly 3-lobed, c. 1.2 by $1.6 \mathrm{~mm}$, greenish; style c. $0.5 \mathrm{~mm}$ long; stigmas c. $1.5 \mathrm{~mm}$ long, cream to purple, apically slightly split. Fruits $1.6-1.8 \mathrm{~cm}$ diam, (green to) pale green to yellowish green; pedicels $(25-) 30-70$ by $0.4-0.9 \mathrm{~mm}$, straight, not widening towards apex, often somewhat striate when dry, apically remaining somewhat puberulous; sepals enlarged, elliptic, widest in the middle, (10-)13-22 by $9-15$ $\mathrm{mm}$, margin entire, apex rounded, venation parallel, 4-8 main veins, basally slightly hairy outside, otherwise glabrous; wall with knobbly surface, sericeous, especially when developing fur-like, thin; columella 5.5-7 mm long, fibrous after dehiscence. Seeds (6-)8.5-9(-12) $\mathrm{mm}$ long, (4-)7-8(-9.5) $\mathrm{mm}$ wide, (4-)5-7(-8) $\mathrm{mm}$ high, widened seeds $8-9 \mathrm{~mm}$ long, $8-9 \mathrm{~mm}$ wide, $6.5-7 \mathrm{~mm}$ high.

Distribution - S South-western and Peninsular Thailand, N Malay Peninsula.

Habitat \& Ecology - Evergreen forest; soil: limestone or rarely granite. Altitude: sea-level up to $200(-457) \mathrm{m}$. Flowering and fruiting: more or less throughout the year.
Notes -1 . Typical for the species are the enlarged sepals of the calyx when fruiting, the sericeous fruit wall and the long straight fruiting pedicels. When not fruiting this species is easily confused with $A$. subsessilis (see note under latter for differences).

2. Actephila collinsae, also a species with enlarged sepals in fruit, is endemic in SW Thailand and partly overlaps in distribution with $A$. ovalis in the province Prachuap Khiri Khan (SW Thailand). Actephila ovalis differs from $A$. collinsae in the leaf apex (obtuse to bluntly acute in $A$. collinsae vs acuminate to cuspidate in $A$. ovalis), leaf margin (flat in $A$. collinsae, wavy in A. ovalis) and fruiting pedicel and sepals (glabrous in A. collinsae vs slightly hairy on the apical pedicel part and basal sepal part outside in A. ovalis).

3. Gagnepain described several Indochinese species (1925: A. macrantha; 1924: A. nitidula, A. pierrei and A. platysepala) with enlarged sepals in fruit. These have not been assessed, but as they were published later than the epithets collinsae and ovalis, a possible synonymization will not invoke a name change. 


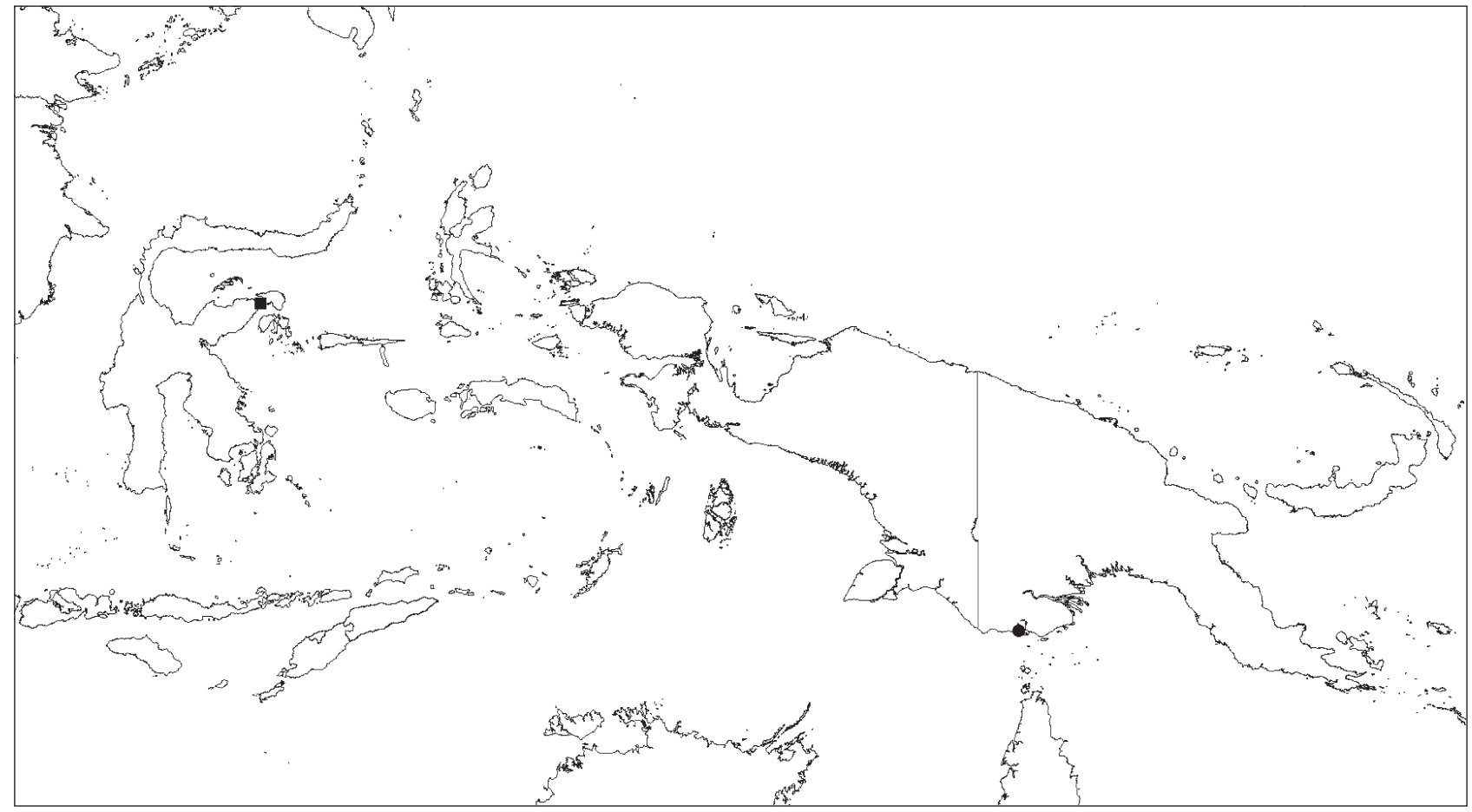

Map 6 Distribution of Actephila stipularis Heijkoop \& Welzen (squares, Sulawesi) and A. trichogyna Airy Shaw (dots, New Guinea).

\section{Actephila stipularis Heijkoop \& Welzen, sp. nov. - Fig. 7;} Map 6

Resembles A. lindleyi most closely in having thick, short, sturdy pedicels paired with a thin nectar disc in fruit, similar petiole lengths and long, slender leaf blades. Typical for $A$. stipularis are large stipules, flattened petioles, and a smooth fruit wall surface. - Type: Coode 5916 (holo L 2 sheets; iso $\mathrm{K})$, Indonesia, Sulawesi, Luwuk area, Sulawesi Tengah, Biak to Poh road; $\mathrm{SO}^{\circ} 49^{\prime} \mathrm{E} 122^{\circ} 47^{\prime}$.

Shrubs, up to $1.2 \mathrm{~m}$ high, monocaul to sparsely branched with 1 or 2 short branches; flowering branches 5-8 mm diam, with brown lenticels. Indumentum: subglabrous on petioles, leaves and sepals. Stipules large, triangular or ovate, c. 8 by $3 \mathrm{~mm}$, glabrous. Leaves: petioles 4-18 mm long, sometimes somewhat sericeous, completely pulvinate, somewhat flattened, becoming corky with age; blade elliptic to sometimes slightly obovate, $13.3-37.5$ by $4.9-9.3,2.7-4$ times as long as wide, papyraceous to pergamentaceous, base acute to somewhat obtuse, margin flat, apex gradually tapering into a widely cuspidate apex, tip acute, abaxially sometimes somewhat sericeous on midrib, often glabrous; nerves c. 14 per side. Flowers solitary to paired to fascicled on brachyblasts after several seasons, white. Staminate flowers not seen. Pistillate flowers not seen, in fruit: white; sepals ovate, widest just below the middle, c. 5 by $3 \mathrm{~mm}$, apex obtuse; petals c. 1.5 by $1.3 \mathrm{~mm}$, apex slightly emarginate, erose; disc a narrow, thin ring, slightly covering base of sepals in fruit. Fruits c. $2 \mathrm{~cm}$ diam, green; pedicels thick, c. 12 by $1.5 \mathrm{~mm}$, slightly wider at apex, straight, glabrous, striate when dry; sepals not enlarging, reflexed; fruit wall smooth, thin, with 6 indistinct lines of dehiscence; columella c. $10 \mathrm{~mm}$ long, basally completely covering the disc, slightly covering the base of the sepals, fibrous after dehiscence. Seeds c. $10 \mathrm{~mm}$ long, c. $8 \mathrm{~mm}$ wide, c. $7 \mathrm{~mm}$ high; widened seeds not seen.

Distribution - Sulawesi (known from type only).

Habitat \& Ecology — Forest in steep valleys. Soil: upraised coralline limestone. Altitude: $300 \mathrm{~m}$. Flowering and fruiting: October.

Note - Typical for the species are the large stipules of c. 8 by $3 \mathrm{~mm}$, in combination with large leaf blades and big fruits on sturdy, thick, short pedicels. The petioles are wide and appear to be flattened. The fruits are completely smooth on the surface and lines of dehiscence are indistinct.

\section{Actephila subsessilis Gagnep. — Map 7}

Actephila subsessilis Gagnep. (1924) 569; (1927) 534. - Syntypes: Bon 667 (P 2 sheets), [Vietnam,] Tonkin, région de Ninh-binh, Hao-nho; Bon $2102(P)$, [Vietnam,] Tonkin, région de Hanoï, Kiên-khé, dans les monts Dong-hâm; Bon 5726 (P 3 sheets), [Vietnam,] Prov. Thanh-hoa, Mâk-són; Eberhardt 4263 (P 2 sheets), [Vietnam,] Prov. Hoa-binh, Mai-chau; Pételo 1172 (P), [Vietnam,] Cho-ganh; Pételot 1173 (P 2 sheets), [Vietnam,] Choganh; Pételot 1275 (P 3 sheets; one noted as 127 in JSTOR website), [Vietnam,] Cho-ganh; Poilane 1658 (P 2 sheets), [Vietnam,] Annam, Thanhhóa (collector numbers of Pételot not mentioned by Gagnepain 1924).

Actephila excelsa (Dalzell) Müll.Arg. var. acuminata Airy Shaw (1972) 209; Whitmore (1973) 52. - Type: Ridley s.n. (holo K), Malaysia, Selangor, Batu caves.

Shrubs to trees; flowering branches with brown lenticels, puberulous, $1.2-3 \mathrm{~mm}$ diam. Indumentum: most parts subglabrous. Stipules triangular or ovate, $2-3$ by $0.8-1 \mathrm{~mm}$, outside somewhat sericeous when young. Leaves: petioles $1-6(-8) \mathrm{mm}$ long, completely pulvinate, puberulous when young, glabrescent; blade elliptic, $5.6-15$ by $2.1-5.2 \mathrm{~cm}, 2.3-3.7$ times as long as wide, papyraceous, base obtuse or acute, margin flat, apex cuspidate to gradually tapering into a widely cuspidate apex, abaxially basally somewhat puberulous on blade and venation; nerves 9-15 per side. Flowers solitary or paired, probably forming small brachyblasts when older. Staminate flowers unknown. Pistillate flowers c. $4 \mathrm{~mm}$ diam, yellow; pedicels 12-30 $\mathrm{mm}$ long, widening towards apex, slightly sericeous towards apex; sepals ovate to elliptic or diamond shaped, widest just below the middle, c. $2-3$ by $1-1.5 \mathrm{~mm}$, apex obtuse; petals $0.8-1$ by $0.4-0.8 \mathrm{~mm}$, apex truncate to rounded, erose; disc a thin, narrow ring, slightly covering the base of the sepals in fruit; ovary c. 0.8 by $1.1 \mathrm{~mm}$, glabrous, stigmas c. $0.5 \mathrm{~mm}$ long. Fruits green, c. $15 \mathrm{~mm}$ diam, pendent; pedicels 17-32 by $0.5-1 \mathrm{~mm}$, somewhat curved, glabrous to sericeous; sepals not elongating, reflexed; fruit wall slightly knobbly outside and with a slightly elevated reticulate venation pattern, glabrous (to slightly sericeous), thin; columella short, sturdy, 4-6 mm long, basally completely covering disc and base of sepals, fibrous 


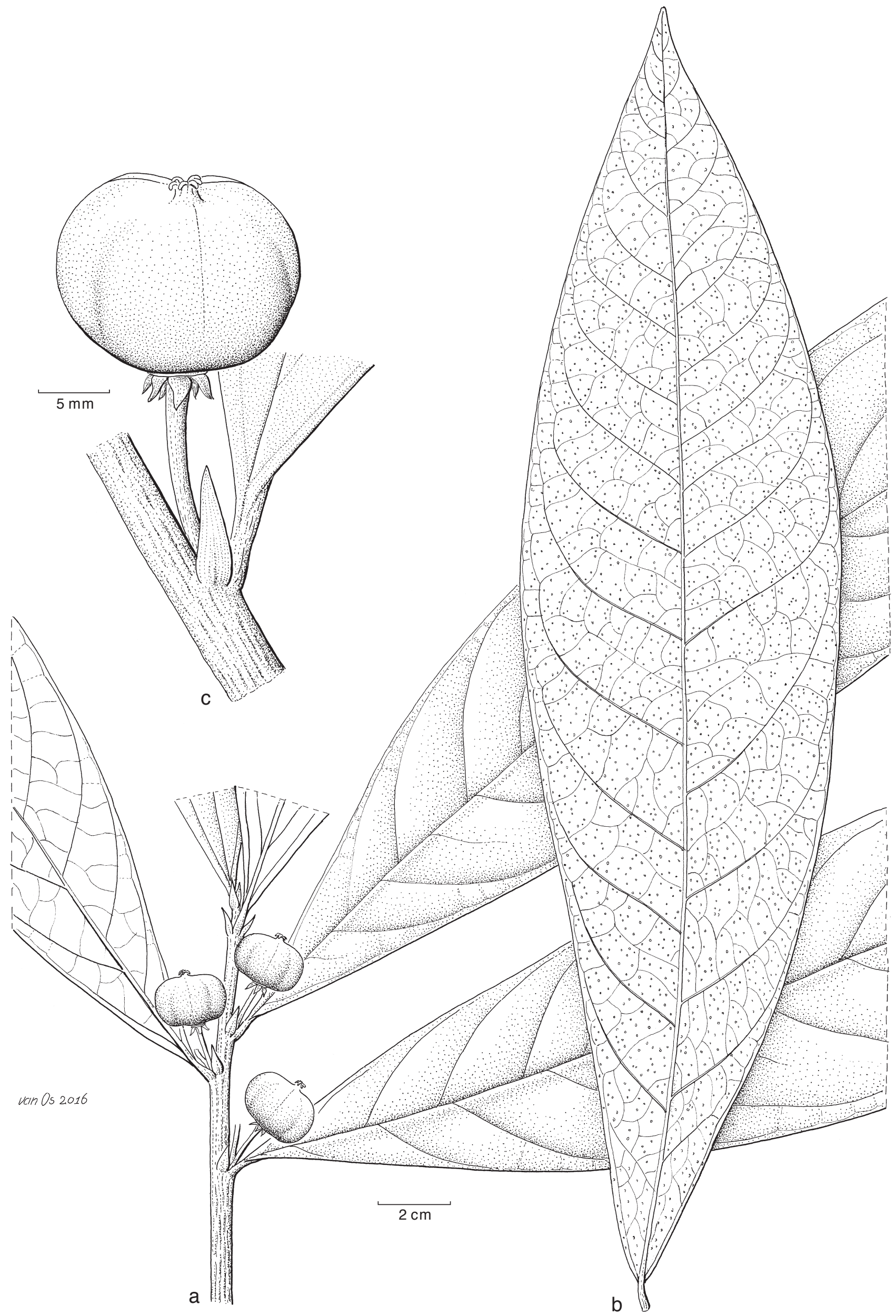

Fig. 7 Actephila stipularis Heijkoop \& Welzen (Phyllanthaceae; formerly Euphorbiaceae). a. Habit, note large stipules; b. leaf, abaxial surface, the dots are damaged areas; c. fruit and large stipule (Coode 5916, L). — Drawing by Jan van Os, 2016. 


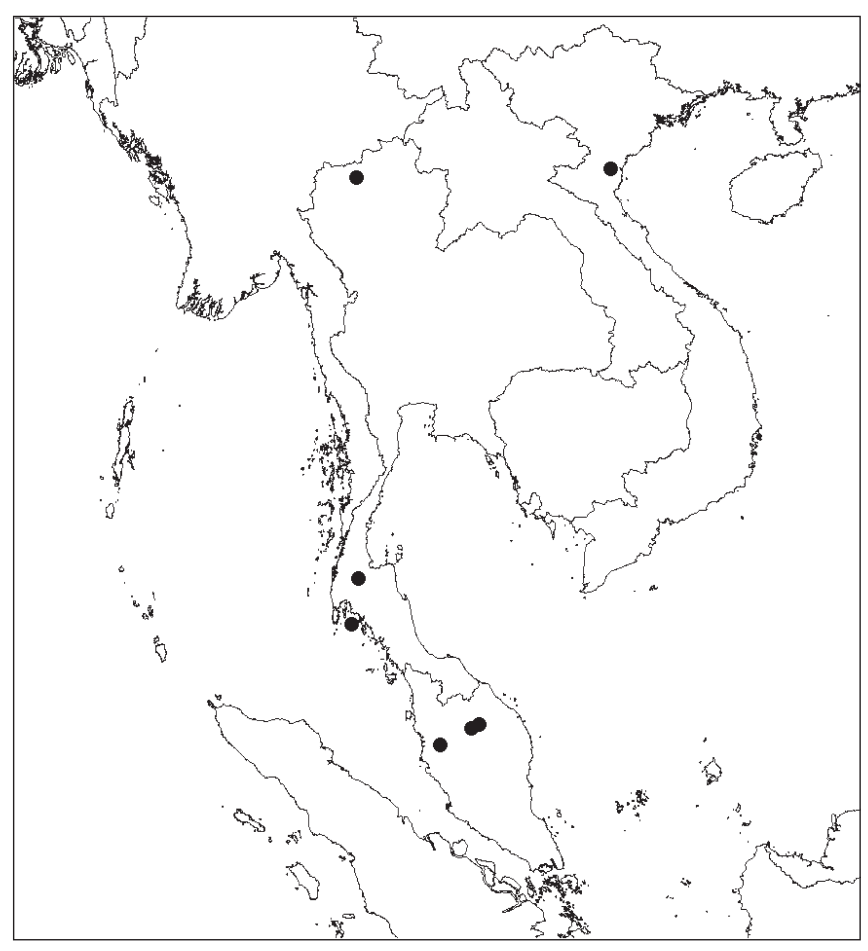

Map 7 Distribution of Actephila subsessilis Gagnep.

after dehiscence. Seeds 7-9.5 mm long, 6-7.5 mm wide, 5-6 $\mathrm{mm}$ high, widened seeds c. $8 \mathrm{~mm}$ long, $9.5-10.5 \mathrm{~mm}$ wide, 6-7 mm high.

Distribution - Thailand, Vietnam, Malay Peninsula.

Habitat \& Ecology - Only found on limestone. Altitude: 50-550 m. Flowering: April, July; fruiting: September, December, January.

Note - This species is vegetatively easily confused with A. ovalis, also present in the Malay Peninsula. Differences are the wavy instead of straight leaf blade margin of $A$. ovalis, and the accrescent calyx in $A$. ovalis up to $10-22$ by $9-13 \mathrm{~mm}$ (against c. 2 by $1.4 \mathrm{~mm}$ in $A$. subsessilis).

\section{Actephila trichogyna Airy Shaw - Map 6}

Actephila trichogyna Airy Shaw (1971) 499; (1980a) 23. - Type: Brass 8417 (holo L 2 sheets; iso A, BRI), Papua New Guinea, Western Division, Tarara, Wassi Kussa River.

Trees, 4-5 m high; flowering branches 1-1.75 mm diam, lenticels indistinct, apically puberulous. Indumentum: most parts subglabrous, simple hairs. Stipules triangular or ovate, $1.6-2$ by 0.8-1 mm, glabrous. Leaves alternate to subopposite at branch ends; petioles $2-4 \mathrm{~mm}$ long, sericeous when young, completely pulvinate; blade elliptic, $5.4-9$ by $2.9-4.1 \mathrm{~cm}, 1.9-2.2$ times as long as wide, papyraceous, base acute or obtuse, margin flat, apex obtuse to somewhat acuminate, abaxially somewhat sericeous on midrib when young; nerves 10-13 per side. Flowers green, solitary or paired; sepals: margin membranous, apex obtuse; disc a wide, somewhat fleshy ring. Staminate flowers c. $3 \mathrm{~mm}$ diam; pedicel c. $5 \mathrm{~mm}$ long, not widening towards apex, glabrous; sepals elliptic, widest in the middle, $1.1-1.2$ by c. $1 \mathrm{~mm}$, outside slightly sericeous, inside glabrous; petals not seen; disc substantially covering base of sepals; stamens: filaments c. $2 \mathrm{~mm}$ long; pistillode not seen, covered by a bundle of hairs. Pistillate flowers not seen; observations from developing fruit: sepals elliptic to somewhat obovate, widest just above to in the middle, $3.5-4$ by c. $2 \mathrm{~mm}$, sericeous on both sides; petals $1-1.2$ by c. $0.4 \mathrm{~mm}$, apex rounded, erose; disc substantially covering base of sepals in fruit; ovary strongly sericeous. (Developing) fruits immature globose, mature probably subglobose and flat- tened; pedicels $13-20$ by $0.5-1 \mathrm{~mm}$, slightly widening towards apex, often slightly sericeous, sometimes glabrous, slightly striate when dry; sepals not elongating; wall strongly sericeous, thin; columella not seen. Seeds not seen.

Distribution - Papua New Guinea (Western Division).

Habitat \& Ecology - Melaleuca leucadendron swampforest. Flowering (and starting to fruit): December.

Note - Typical for the species are the small leaf blades up to 9 by $4.1 \mathrm{~cm}$, and the short delicate petioles (up to $4 \mathrm{~mm}$ long). The fruits are small, but this is probably due to immaturity. Developing fruits resemble $A$. ovalis in being heavily sericeous with a wide fleshy disc underneath, covering the base of the sepals. However, the sepals are not enlarged and the general leaf blade and stipule shape does not resemble $A$. ovalis. Staminate flowers have a bundle of hairs instead of a pistillode, it remains unclear whether a pistillode is present underneath.

\section{Actephila sp. nov.? (BW (Koster) 4344)}

Shrub, c. $1.75 \mathrm{~m}$ high; flowering branches 3-5 mm diam. Indumentum absent. Stipules triangular or narrowly ovate, c. 4 by $2 \mathrm{~mm}$, glabrous. Leaves petioles 13-23 mm long, pulvinate at base, with corky edges when older; blade slightly obovate, $21-29$ by $6.4-7.6 \mathrm{~cm}, 3.3-3.8$ times as long as wide, pergamentaceous, base attenuate, tapering into petiole, margin flat, apex acute to somewhat acuminate; nerves 15-18 per side, becoming inconspicuous near margin. Flowers on axillary brachyblasts. Staminate flowers (in bud) white with purple tinge; sepals ovate, apex obtuse, margin membranous, glabrous on both sides; petals 5; disc a complete ring, somewhat lobed, surrounding stamens, folded upwards at the edges; stamens with filaments connate at base. Pistillate flowers, fruits and seeds unknown.

Distribution - New Guinea (Indonesian Papua: Sowi-Rendani, near Manokwari).

Habitat \& Ecology - Locally rather common in primary forest on clayey soil. Altitude: c. 150 m. Flowering: July.

Note - The specimen strongly resembles A. lindleyi. However, the stipules are larger, the blade is slightly obovate with an elongated attenuate base and a short, acute apex, a shape not observed in $A$. lindleyi specimens. Moreover, this specimen has more secondary veins than the $A$. lindleyi specimens studied. More specimens are needed to certify the status of this specimen as only young staminate flowers were seen.

\section{EXCLUDED TAXA}

Actephila aurantiaca Ridl. (1923) 360; (1924) 197. - Type: Ridley s.n., Feb. 1917 (holo K), [Malaysia,] Kelantan, Kelantan River, Chaning. = Trigonostemon aurantiacus (Kurz ex Teijsm. \& Binn.) Boerl.

Actephila flaviflora Lauterb. \& K.Schum. in Schumann \& Lauterbach (1900) 388. - Syntypes: Hollrung 481 (K), Kaiser Wilhelmsland (= Papua New Guinea), Constantinhafen, Gagar Fluss (Gagar River); Lauterbach 957 (not seen), Kaiser Wilhelmsland, Mittellauf Gogol Fluss (central part Gogol River); Lauterbach 2882 (as 882 in K), Kaiser Wilhelmsland, Nurufluss (Nuru River). = Phyllanthus flaviflorus (Lauterb. \& K.Schum.) Airy Shaw (1980a) 22.

Actephila megistophylla Quisumb. \& Merr. (1928) 158. — Lectotype (designated by Kulju \& Van Welzen 2005): BS (Ramos \& Edaño) 45466 (holo A; iso K, NY, US), Philippines, Luzon, Tayabas Prov., Casiguran $=$ Cleidion megistophyllum (Quisumb. \& Merr.) Airy Shaw (1971) 528; Kulju \& Van Welzen 2005) 215). 
Acknowledgements The directors and keepers of A, BM, BRI, E, G, GH, HBG, K, L, MO, NY, P, PC, SING, US are thanked for use of their material, either as loan or via photos. Esmée Winkel and Jan van Os are thanked for the beautiful drawings.

\section{REFERENCES}

Airy Shaw HK. 1971. Notes on Malesian and other Asiatic Euphorbiaceae. CXXVII. The genus Actephila BI. in eastern Malesia and Australia. Kew Bulletin 25: 496-500.

Airy Shaw HK. 1972. The Euphorbiaceae of Siam. Kew Bulletin 26: 191-363.

Airy Shaw HK. 1975. The Euphorbiaceae of Borneo. Kew Bulletin, Additional Series 4: 1-245.

Airy Shaw HK. 1978. Notes on Malesian and other Asiatic Euphorbiaceae. CXCII. A new species of Actephila BI. from New Guinea. Kew Bulletin 32: 361-418.

Airy Shaw HK. 1980a. The Euphorbiaceae of New Guinea. Kew Bulletin, Additional Series 8: 1-243.

Airy Shaw HK. 1980b. New or noteworthy Australian Euphorbiaceae-II. Muelleria 4: 207-245.

Airy Shaw HK. 1980c. A partial synopsis of the Euphorbiaceae-Platylobeae of Australia (excluding Phyllanthus, Euphorbia and Calycopeplus). Kew Bulletin 35: 577-700.

Airy Shaw HK. 1981. The Euphorbiaceae of Sumatra. Kew Bulletin 36: 239374

Airy Shaw HK. 1982. The Euphorbiaceae of Central Malesia (Celebes, Moluccas, Lesser Sunda Is.). Kew Bulletin 37: 1-40.

Airy Shaw HK. 1983. An alphabetical enumeration of the Euphorbiaceae of the Philippine Islands. Royal Botanic Gardens, Kew.

Aiton WT. 1813. Hortus Kewensis, 2nd ed, 5. Longman, Hurst, Rees, Orme \& Brown, London.

Anderson RH. 1968. The trees of New South Wales, 4th ed. VCN Blight, Sydney.

APG (Angiosperm Phylogeny Group). 2003. An update of the angiosperm phylogeny group classification for the orders and families of flowering plants: APGII. Botanical Journal of the Linnean Society 141: 399-436.

Backer CA, Bakhuizen van den Brink Jr RC. 1963. Flora of Java 1. Noordhoff, Groningen.

Bailey FM. 1902. The Queensland Flora 5. Diddams \& Co., Brisbane.

Baillon MH. 1858. Étude Générale du groupe des Euphorbiacées. Librairie de Victor Masson, Paris.

Baillon MH. 1866. Species Euphorbiacearum. Euphorbiacées Australiennes. Adansonia 6: 282-345.

Balachandran N, Maheswaran B, Chakrabarty T. 2009. A new variety of Actephila excelsa (Dalzell) Muell.-Arg. (Euphorbiaceae) from North Andaman Island. Journal of Economic and Taxonomic Botany 33: 717-718.

Beadle NCW, Evans OD, Carolin RC. 1972. Flora of the Sydney Region, rev. ed. AH \& AW Reed, Sydney.

Beadle NCW, Evans OD, Carolin RC. 1982. Flora of the Sydney Region, 3rd ed. AH \& AW Reed, Sydney.

Bentham G. 1873. Flora Australiensis 6. Reeve \& Co, London.

Bentham G. 1880. Ordo CLI. Euphorbiaceae. In: Bentham G, Hooker JD (eds), Genera Plantarum 3. Reeve \& Co, Londini.

Blume CL. 1826. Bijdragen tot de Flora van Nederlandsch Indië 12. Lands Drukkerij, Batavia.

Chase MW, Zmartzty S, Lledo MD, et al. 2002. When in doubt put it in Flacourtiaceae: A molecular phylogenetic analysis based on plastid rbcL DNA sequences. Kew Bulletin 57: 141-181.

Chayamarit K. 2005. Actephila. In: Chayamarit K, Van Welzen PC (eds), Euphorbiaceae (Genera A-F). In: Santisuk T, Larsen K (eds), Flora of Thailand 8, 1: 34-40. The Forest Herbarium, Bangkok.

Croizat L. 1942. On certain Euphorbiaceae from the tropical Far East. Journal of the Arnold Arboretum 23: 29-54.

Dalzell NA. 1851. Contributions to the botany of Western India. Hooker's Journal of Botany and Kew Garden Miscellany 3: 225-232.

De Jussieu A. 1824. De Euphorbiacearum Generibus. Didot Junioris, Parisiis. Drake del Castillo E. 1892. Illustrationes Florae Insularum Maris Pacifici. Masson, Parisiis.

Drake del Castillo E. 1893. Flore de la Polynésie Française. Masson, Paris.

Elmer ADE. 1908. A century of new plants. Leaflets of Philippine Botany 1: 272-359.

Elmer ADE. 1910. Euphorbiaceae collected on Sibuyan Island. Leaflets of Philippine Botany 3: 903-931.

Endlicher S. 1840. Genera Plantarum 16. Fr Beck, Vindobonae.

Forster PI. 2005. A taxonomic revision of Actephila Blume (Euphorbiaceae/ Phyllanthaceae) in Australia. Austrobaileya 7: 57-98.
Gage AT. 1922. Euphorbiaceae novae e Peninsula Malayana. Records of the Botanical Survey of India 9: 219-249.

Gage AT. 1936. Materials for a Flora of the Malayan Peninsula, no. 26. Journal of the Asiatic Society of Bengal, part 2, Natural History 75: 469-544. Gagnepain F. 1924. Euphorbiacées nouvelles (Actephila et Cleidion). Bulletin de la Société Botanique de France 71: 566-570.

Gagnepain F. 1925. Euphorbiacées nouvelles (Antidesma, Actephila, Baliospermum, Blachia, Cleistanthus, Croton, Daphniphyllum, Epiprinus, Mallotus, Nephrostylus, n.g., Poilaniella, n.v., Prosartema, Trigonostemon). Bulletin de la Société Botanique de France 72: 458-470.

Gagnepain F. 1927. Euphorbiaceae. In: Lecomte MH (ed), Flore Générale de l'Indo-Chine 5. Masson et Cie, Paris.

Govaerts R, Frodin DG, Radcliffe-Smith A. 2000. World checklist and bibliography of Euphorbiaceae (and Pandaceae) 1. Royal Botanic Gardens, Kew. Hasskarl JK. 1844. Catalogus Plantarum in Horto Botanico Bogoriensi cultarum alter. Lands-drukkerij, Batavia

Henderson MR. 1939. The Flora of the Limestone Hills of the Malay Peninsula. Journal of the Malayan Branch of the Royal Asiatic Society 17: 13-87.

Hoffmann P, Kathriarachchi H, Wurdack KJ. 2006. A phylogenetic classification of Phyllanthaceae (Malpighiales; Euphorbiaceae sensu lato). Kew Bulletin 61: 37-53

Hooker JD. 1887. The Flora of British India 5. Reeve \& Co., London.

Koorders SH. 1897. Verslag eener botanische dienstreis door de Minahasa. Mededeelingen van 's Lands Plantentuin 19: 1-716.

Kulju KKM, Van Welzen PC. 2005. Revision of the genus Cleidion (Euphorbiaceae) in Malesia. Blumea 50: 197-219.

Kurz S. 1877. Forest Flora of British Burma 2. Office of the Superintendent of Government Printing, Calcutta.

Lindley J. 1821. Collectanea Botanica. Richard \& Arthur Taylor, London.

Merrill ED. 1909. New or noteworthy Philippine plants, VII. The Philippine Journal of Science 4, Botany: 247-330.

Merrill ED. 1923. An enumeration of Philippine flowering plants. Bureau of Printing, Manila.

Merrill ED. 1929. Plantae Elmerianae Borneenses. University of California Press, Berkeley.

Miers J. 1851. A few remarks on the Menispermaceae. The Annals and Magazine of Natural History 2nd ser., 7: 33-45.

Miquel FAW. 1859. Flora van Nederlandsch Indië 1, 2. Van der Post, Amsterdam.

Müller (Argoviensis) J. 1863. Euphorbiaceae. Linnaea 32: 1-126.

Müller (Argoviensis) J. 1865. Euphorbiaceae. Linnaea 34: 1-224

Müller (Argoviensis) J. 1866. Euphorbiaceae. In: De Candolle AP (ed), Prodromus Systematis Naturalis Regni Vegetabilis 15, 2. Masson \& Filii, Paris Nadeaud J. 1873. Énumération des Plantes indigènes de l'lle de Tahiti. Savy, Paris.

Pax F, Hoffmann K. 1912. Euphorbiaceae-Hippomaneae. In: Engler A (ed), Das Pflanzenreich IV.147.v. Engelmann, Leipzig.

Pax F, Hoffmann K. 1922. Euphorbiaceae-Phyllanthoideae-Phyllantheae. In: Engler A (ed), Das Pflanzenreich IV.147.xv. Engelmann, Leipzig.

Pax F, Hoffmann K. 1931. Euphorbiaceae. In: Engler A, Harms H (eds), Die Natürlichen Pflanzenfamilien, 2nd ed, 19c: 11-233. Engelmann, Leipzig. Quisumbing E, Merrill ED. 1928. New Philippine plants. Philippine Journal of Science 37: 133-212.

Radcliffe-Smith A. 2001. Genera Euphorbiacearum. Royal Botanic Gardens, Kew.

Ridley HN. 1911. The Flora of Lower Siam. Journal of the Straits Branch of the Royal Asiatic Society 59: 15-234.

Ridley HN. 1923. XXXVIII. - New Euphorbiaceae of the Malay Peninsula. Bulletin of Miscellaneous Information, Kew: 360-369.

Ridley HN. 1924. The Flora of the Malay Peninsula 3. Reeve \& Co Ltd, Ashford, Kent.

Samuel R, Kathriarachchi H, Hoffmann P, et al. 2005. Molecular phylogenetics of Phyllanthaceae: Evidence from plastid matK and nuclear PHYC sequences. American Journal of Botany 92: 132-141.

Schumann KM, Lauterbach KAG. 1900. Die Flora der Deutschen Schutzgebiete in der Südsee. Borntraeger, Leipzig.

Smith JJ. 1910. Euphorbiaceae. In: Koorders SH, Valeton T (eds), Boomsoorten op Java 12. Mededeelingen uitgaande van het Departement van Landbouw in Nederlandsch-Indië 10: 9-637.

Smitinand T. 1961. Some noteworthy plants from Thailand (Siam). The Natural History Bulletin of Siam Society 20: 41-70.

Smitinand T. 1962. New records of plants from Thailand - II. The Natural History Bulletin of Siam Society 20: 121-139.

Steudel ET. 1841. Nomenclator Botanicus 2, 2. JG Cottae, Stuttgartiae, Tubingae. 
Van der Ent A, Van Balgooy MMJ, Van Welzen PC. 2016. Actephila alanbakeri (Phyllanthaceae): a new nickel hyperaccumulating plant species from localised ultramafic outcrops in Sabah (Malaysia). Botanical Studies 57, 6: 1-8 (doi: https://doi.org/10.1186/s40529-016-0122-1).

Vorontsova MS, Hoffmann P. 2008. A phylogenetic classification of tribe Poranthereae (Phyllanthaceae, Euphorbiaceae sensu lato). Kew Bulletin 63: 41-59.

Wallich N. 1828. A numerical list of dried specimens. Company's botanic garden, Calcutta.

Webster GL. 1994. Synopsis of the genera and suprageneric taxa of Euphorbiaceae. Annals of the Missouri Botanical Garden 81: 33-144.
Webster GL. 2014. Euphorbiaceae. In: Kubitzki K (ed), The families and genera of vascular plants 11, Malpighiales: 51-216. Springer Verlag, Berlin, Heidelberg.

Whitmore TC. 1973. Tree Flora of Malaya 2. Longman, London.

Wight R. 1852. Icones Plantarum Indiae Orientalis 5. Franck \& Co, Madras. Wurdack KJ, Hoffman P, Samuel R, et al. 2004. Molecular phylogenetic analysis of Phyllanthaceae (Phyllanthoideae pro parte, Euphorbiaceae sensu lato) using plastid rbcl DNA sequences. American Journal of Botany 91: 1882-1900.

\section{IDENTIFICATION LIST OF ACTEPHILA SPECIMENS}

$$
\begin{aligned}
& 1=\text { A. alanbakeri } \\
& 2=\text { A. discoidea } \\
& 3=\text { A. dolichopoda } \\
& 4=\text { A. emarginata }
\end{aligned}
$$

Achmad 1778: 5 - Aët \& Idjan 342 (1939): 7 - Afriastini 1243: 5 - Argent 9932: 5 - Axelius 174: 5 .

Backer 27881: 5; 36980: 5 - Balakrishnan 84: 5 - Bhargava 3794: 5 - Bhargava \& Nair 2267: 5 - Bhargava et al. 6336: 5 - Blume 1670: 5 - BodenKloss 10578: 5; 14667: 5 - Bogor Botanical Garden IX.C.90: 5; XII.B.271: 5; XII.B.VII.151: 5 - Bon 667: 10; 2101: 10; 5726: 10 - Brass 8417: 11; 29350: 4; 32390: 7 - BRUN series 16862: 5; 16892: 5 - BS series 36673: 5; 49158: 5; 78238: 5 - BSIP series 7801: 7; 8352: 7 - Bunchuai 1279: 10 - Buwalda 4332: 6; 5131: 7; 5188: 7; 5738: 7 - BW series 4161: 7; 15063: $7 ; 15284: 7$.

Carr 11774: 3; 11775: 3 - Chen 9754: 8 - Chin 1752: 8 - Coode 5916: 9 - Curtis 2379: 10

De Vogel 1634: 5; 2771: 5; 3223: 7 - De Wilde \& De Wilde-Duyfjes 20230: 5 Eberhardt 4263: 10 - Elmer 7245: 5; 12141: 5; 12303: 5; 12621: 5; 20722: 5- Endert 5154: 5.

Forbes 3112a: 5 - Forster, Booth \& Jensen 28120: 6 - Forster \& Jensen 29786: 6 - Forster \& McDonald 8030: 6; 8318: 6 - Fukuoka \& Ito T-35435: 5.

Geesink, Hiepko \& Charoenphol 7513: 5 - Geesink, Hiepko \& Phengkhlai 7729: 8 - Geesink, Phanichapol \& Santisuk 5760: 5 - Geesink \& Santisuk 5277: 5 - Goklin 2401: 5.

Hallier 336: 5 - Hartley 13074: 4.

Iboet 71 (1924): 5; 419 (1924): 5.

Jacobs 9538: 2 - Jayasuriya 848: 5; 926: 5; 1297: 5; 1717: 5.

Kadim \& Noor 648: 5 - Kuswata Kartawinata 867: 5 - Kathriarachchi, Hoffmann \& Galster 60: 5 - Kato et al. C-7094: 7 - KEP FRI series 1799: 10; 4239: 10; 5320: 5; 19212: 5; 37262: 5; 65742: 8 - Kerr 9561: 5; 11173: 8; 11470: 8; 11820: 5; 12616: 8; 12982: 8; 13660: 5; 16025: 8; 16059: 5; 17018: 5; 18249: 8; 18660: 5; 18910: 10; 21689: 8 - Koelz 29845: 5 - Koorders 2738: 5; 10002: 5; 16937: 5; 26891: 5; 28728: 5; 30269: 5; 39682: 5 - Kostermans 638: 7; 19291: 5; 28719: 5 - Kostermans \& Soegeng-Reksodihardjo 161: 7 - Krukoff 4407: 5.

$\begin{aligned}= & \text { A. excelsa } & 9 & =\text { A. stipularis } \\ & \text { A. latifolia } & 10 & =\text { A. subsessilis } \\ & =\text { A. lindleyi } & 11 & =\text { A. trichogyna }\end{aligned}$

A. ovalis

LAE series 50086: 7; 62117: 3; 74726: 2 - Larsen \& Larsen 33411: 5 - Larsen et al. 31059: 8; 45482: 5 .

Maxwell 05-615: 5; 75-836: 5; 75-883: 8; 81-49: 5; 85-403: 5; 86-264: 5; 86503: 8; 89-120: 10; 93-664: 5 - McDonald \& Afriastini 3328: 5 - Middleton et al. 378: 5 ; 487: 8; 1495: 8; 4291: 8; 4674: 5 - Mondih 220: 5 .

NGF series 18987: 7; 26551: 7; 31902: 7; 39246: 7; 46983: 7; 48299: 2; 49220: 7; 49221: 7 - Noor 1915: 5 - Noor \& Samsuri 14: 5 - Nooteboom 5727: 7 ; 5755: 7 ; 5843: 7 .

Pételot 1172: 10; 1173: 10; 1275: 10 - Pleyte 338 (1948): 7 - PNH series 1932: 1; 11103: 5; 13727: 5; 42195: 5 - Poilane 1658: 10 - Pooma, Pattharahirantricin \& Sirimongkol 6498: 5 - Pooma et al. 2502: 5 - PPI series 387 : 5; 5746: 5; 6964: 5; 11774: 5; 24769: 5; 36047: 1 - Put 711: 8.

Rachmat 16: 5 - Ramos 1781: 5 - Rappard 168: 5 - Ridley 8352: 5; 8530: 10; 11046: 5; 13375: 10; 14090: 8; 14890: 8 .

S series 38542: 5; 41809: 5 - Hoang Van Sam 102: 10 - Samsuri Ahmad 820: 5 - SAN series 30673: 5; 31206: 5; 35573: 5; 89551: 5; 115287: 5; 126262: 5 ; 130671 : 5 ; 141043: 5 ; 145750: 1 ; 151107: 1 - Sands \& Jermy 1244: 2 - Santisuk \& B.N. 308: 8 - SFN series 18568: 5; 19521: 10; 21204 8; 23005: 8; 29111: 8; 35247: 8; 37688: 8; 37689: 8; 40393: 5 - Shah \& Samsuri 1729: 5 - Shimizu, Fukuoka \& Nalampoon T-7971: 8 - SING series 2012-385: 5 - Smitinand et al. 1147: 8; 1246: 10 - SNP (series) 38539: 1 - Soejarto \& Cuong 11691: 10 - Soejarto, Xinh \& Quang 13375: 10 - Sumithraarachchi 712: 5 - Suvarnakoses 209: 8.

Takeuchi \& Ama 15681: 2 - Takeuchi \& Towati 14639: 2 -Thwaites 2532: 5. UNESCO 162: 5; 199: 5 - University of San Carlos 98: 5; 284: 5 - UPNG series 4296: 3 .

Van Balgooy 6595: 6 - Van Balgooy \& Mamesah 6400: 6 - Van Beusekom 2674: 5 - Van Beusekom \& Phangkhlai 1039: 8 - Van Beusekom \& Santisuk 2794: 8 - Van Royen 3059: 7; 5296: 7

Wang 79253: 5 - Webb \& Hamid 3430: 5 - Webb \& Tracey 12563: 6 - Wight KD 2574: 5 - Williams et al. 1408: 5 - Wirawan 110: 5

Zollinger 512: 5; 1662: 5 . 